\title{
Postnatal Development of the Tyrosine Hydroxylase-Containing Cell Population within the Rat Locus Coeruleus: Topological Organization and Phenotypic Plasticity
}

\author{
Laurent Bezin, Dominique Marcel, Laure I. Debure, Nathalie Ginovart, Colette Rousset, Jean-François Pujol, \\ and Dinah Weissmann \\ Laboratoire de Neuropharmacologie Moléculaire, CNRS-UCBL UMR 105, CERMET, 69003 Lyon, France
}

The cellular phenotypic characteristics of tyrosine hydroxylase (TH) expression have been studied within the rat locus coeruleus (LC) during postnatal development at six different stages: postnatal day 4 (PND4), PND10, PND14, PND21, PND30, and PND42. Coronal brain sections were selected at intervals of $80 \mu \mathrm{m}$ along the caudorostral extent of the LC and processed for TH immunohistochemistry. At each anatomical level we (1) reconstructed the mean space of the LC delineated by the TH positive cell bodies, (2) enumerated the mean number of these cell bodies, and (3) determined the mean volume circumscribed by these cell bodies and their density. The topological study revealed a steady remodeling of the structure until the third week, with a progressive reducing of a ventral cellular group in the anterior LC, which was no longer observable at PND21, concomitant to the stretch of the structure toward its caudal limit. We have noted invariant and variant cellular phenotypic characteristics of TH expression. At any stage, the LC could be separated into a posterior and an anterior subregion and its total volume remained quite stable during the studied period. At PND14 and PND21, we observed a transient 33\% increase in the total number of TH positive perikarya as compared to PND42. Conjoint analysis of the topological reconstruction and the density of TH positive cells suggested there were three distinct and precisely localized subsets of "quiescent" neurons. TH gene expression in these cells would have lowered between PND14 and PND21 inside two subsets and between PND21 and PND30 inside the last one. So topologically defined populations of cells could be involved in specific functions. If they have not definitively lost their TH expression capacity, they could contribute to increasing TH levels in LC occurring in response to physiological perturbations or pharmacological treatments.

[Key words: tyrosine hydroxylase, locus coeruleus, postnatal development, transient expression, immunohisfochemistry, topology]

\footnotetext{
Received Dec. 14, 1993; revised May 2, 1994; accepted June 2, 1994.

This work was supported by grants from CNRS-UMR 105, Université Claude Bernard Lyon I, DRET (509210), and MRT (91127).

Correspondence should be addressed to Laurent Bezin, CNRS-UCBL UMR 105, CERMEP, 59, Bd Pinel, 69003 Lyon, France.

Copyright (C) 1994 Society for Neuroscience 0270-6474/94/147486-16\$05.00/0
}

The tyrosine hydroxylase [TH: tyrosine 3-monooxygenase, L-tyrosine, tetrahydropteridine: oxygen oxidoreductase (3-hydroxylating), EC 1.14.16.2], the rate-limiting enzyme in the catecholamine (CA) biosynthesis pathway (Nagatsu et al., 1964; Levitt et al., 1965), is detected at early stages of prenatal development within presumptive catecholaminergic neurons (Specht et al., 1981). In the CNS, among the perikarya of the neurons that are clustered in several groups at the adult stage, the cell bodies of the locus coeruleus (LC) neurons undergo deep histological reorganization until they attain their definitive position within the brainstem in the late postnatal period (Sievers et al., 1981).

Most of the LC neurons use noradrenaline (NA) as neurotransmitter at the adult stage (Swanson, 1976; Luque et al., 1992) and the NA released by caeruleal neurons might be involved in the critical periods of brain plasticity and regulate different brain developmental steps (Seiger and Olson, 1973; Maeda et al., 1974; Kasamatsu and Pettigrew, 1976; Wendlandt et al., 1977; Kasamatsu and Pettigrew, 1979; Ebosole et al., 1981; Sievers et al., 1981; Lidov and Molliver, 1982; Parnavelas and Blue, 1982; Kasamatsu et al., 1989). Although the functional importance of the LC appears early in development, there is experimental evidence suggesting that the steady state of the catecholamine content of the LC perikarya is reached late during the postnatal development (Maeda et Dresse, 1969; Sievers et al., 1981). It is for this period of postnatal ontogeny that a physiological induction of TH expression has already been suggested (Zyzek et al., 1990). It has also been hypothesized that plasticity of phenotypic characters of TH expression could occur in the LC at adulthood. Indeed pharmacological treatments (Debure et al., 1992; Blanchard ct al., 1993) or physiological perturbations (Richard et al., 1988; Schmitt et al., 1993) enhance TH expression in the adult rat LC. In one of these models, Debure et al. (1992) reported a significant increase in the number of TH mRNA-/and TH protein-positive cells.

The phenotypic characterization of $\mathrm{TH}$ protein expression in the LC can be defined in terms of TH-expressing cells and expressed TH protein. This study was devoted to the analysis of the postnatal evolution of TH expressing cells. The cellular parameters necessary for the phenotypic characterization of $\mathrm{TH}$ expression were quantitatively determined. They corresponded to the mean number of TH-expressing cells, the mean limit of the space occupied by these cells, the mean volume circumscribed by these cells and the mean density of TH-expressing 
Table 1. Control of age groups by recording the body weight of the rats and experimental conditions (tissue preparation and freezing time of the brains) before TH immunocytochemical processing

\begin{tabular}{|c|c|c|c|c|c|c|}
\hline $\begin{array}{l}\text { Postnatal } \\
\text { age }\end{array}$ & $\begin{array}{l}\text { PND4 } \\
(n=5)\end{array}$ & $\begin{array}{l}\text { PND10 } \\
(n=5)\end{array}$ & $\begin{array}{l}\text { PND14 } \\
(n=5)\end{array}$ & $\begin{array}{l}\text { PND21 } \\
(n=6)\end{array}$ & $\begin{array}{l}\text { PND30 } \\
(n=6)\end{array}$ & $\begin{array}{l}\text { PND42 } \\
(n=6)\end{array}$ \\
\hline \multirow[t]{2}{*}{ Body weight ${ }^{a}$} & 11.77 & 27.67 & 30.48 & 42.19 & 92.13 & 224.00 \\
\hline & \pm 0.61 & \pm 0.65 & \pm 0.4 & \pm 0.59 & \pm 0.79 & \pm 1.66 \\
\hline Tissue fixation & $\begin{array}{l}\text { Fixed by } \\
\text { immersion }\end{array}$ & $\begin{array}{l}\text { Fixed by } \\
\text { immersion }\end{array}$ & Postfixed & Postfixed & Postfixed & Postfixed \\
\hline Freezing time & $30 \mathrm{sec}$ & $50 \mathrm{sec}$ & $50 \mathrm{sec}$ & $1 \mathrm{~min}$ & $1 \mathrm{~min}$ & $1 \mathrm{~min}$ \\
\hline
\end{tabular}

Mean and SEM obtained for $n$ animals.

perikarya. Each of these parameters was examined along the caudorostral extent of the structure at six different postnatal stages: postnatal day 4 (PND4), PND10, PND14, PND21, PND30, and PND42.

\section{Materials and Methods}

Animal and tissue preparation. All experiments were carried out in accordance with the French (87-848, Ministère de l'Agriculture et de la Forêt) and the European Community (86-60, EEC) guidelines for care of laboratory animals and were approved by the regional ethical animal use committee.

OFA male rats (Iffa-Credo, Lyon, France) were considered at different postnatal stages: PND4, PND10, PND14, PND14, PND21, PND30, and PND42. The day of birth was taken as PND0. Distorsions between animals belonging to the same postnatal stage were avoided by recording the body weight of the pups (Table 1). For rats aged from PND4 to PND 14, littcrs arrived at the animalcry with a foster mother $3 \mathrm{~d}$ beforc experiments; those from PND21 to PND42 were kept 1 week under a 12:12 hr dark/light cycle at $21^{\circ} \mathrm{C}$ with food and water ad libitum.

The detection of TH-containing cell bodies by immunohistochemical methods was carried out on postfixed tissue from PND14 to PND42 whereas it was performed on tissue fixed by immersion at PND4 and PND10 because of the fragility of the tissue. After decapitation, the brains were quickly removed from the skull. For PND4 and PND10 rat brains, the brainstem was separated from the rest of the brain and immersed in a cold $\left(4^{\circ} \mathrm{C}\right)$ mixture of $4 \%$ paraformaldehyde (Merck) and $0.2 \%$ picric acid (Sigma) in $0.1 \mathrm{M}$ Sorensen buffer for $72 \mathrm{hr}$. They were then immersed overnight to a cold $\left(4^{\circ} \mathrm{C}\right)$ sucrose solution ( $10 \%$ for PND4 and $20 \%$ for PND10) in $0.1 \mathrm{M}$ Sorensen buffer and snap-frozen by immersion in cooled $\left(-30^{\circ} \mathrm{C}\right.$; Table 1) liquid isopentane (Merck). PND14-PND42 brains were frozen by immersion in isopentane $\left(30^{\circ} \mathrm{C}\right.$ Table 1). During freezing, the ventral side of the brains was carefully set on a plane surface to prevent distorsions of the longitudinal axis of the brain. All brains were stored at $-80^{\circ} \mathrm{C}$ until further use.

Before cutting, the brains were stuck on an object stage. During this process, particular care was taken to set the longitudinal axis of the brain perpendicular to the object stage. So, when the object stage was fixed to the object holder of the cryostat-microtome, the angle value between the knife and the longitudinal axis of the brain was conserved for all brains belonging to each studied age.

Two frontal cryostat-cut sections ( $20 \mu \mathrm{m}$ thick for PND4 and PND10, $10 \mu \mathrm{m}$ thick for PND14-PND42) at $80 \mu \mathrm{m}$ intervals along the caudorostral extent of the LC were collected on $1 \%$ gelatin (Sigma)-coated glass slides. One was processed by TH immunohistochemistry and the adjacent one was stained with cresyl violet for histological reference.

Before the immunohistochemical procedure, sections of brains fixed by immersion were directly rinsed $(3 \times 30 \mathrm{~min})$ with $0.1 \mathrm{M}$ saline phosphate buffer, pH 7.4 (PBS). Sections of fresh-frozen brains were postfixed overnight at $4^{\circ} \mathrm{C}$ by immersion with a solution of $4 \%$ paraformaldehyde in $0.1 \mathrm{M}$ Sorensen buffer. They were then rinsed $3 \times 30$ min with PBS.

Immunohistochemistry. The sections were then processed using peroxidase-antiperoxidase method (Sternberger et al., 1970). We used as primary antibody a polyclonal anti-TH antibody raised in the rabbit against purified rat pheochromocytome tyrosine hydroxylase protein. All incubations were carried out at room temperature $\left(\sim 20^{\circ} \mathrm{C}\right)$, except the incubation in $\mathrm{TH}$ antiserum $\left(4^{\circ} \mathrm{C}\right)$. Sections were sequentially incubated in (1) a PBS solution containing 1\% normal swine serum (NSS;
Dako) for $1 \mathrm{hr}$, (2) a solution of rabbit TH-antiserum (Jacques Boy) finally $1: 10,000(\mathrm{v} / \mathrm{v})$ diluted in PBS- $1 \%$ NSS for $48 \mathrm{hr}$, (3) a solution of anti-rabbit swine immunoglobulins (Dako) 1:500 (v/v) diluted in PBS/1\% NSS, (4) a solution of peroxidase-antiperoxidase complex (Dako) $1: 500(\mathrm{v} / \mathrm{v})$ diluted in PBS/1\% NSS. Between each of these four steps, sections were rinsed $3 \times 30 \mathrm{~min}$. All rinses were made in $0.1 \mathrm{M}$ PBS solutions containing $0.1 \%$ NSS. Control sections were processed in parallel, leaving out the primary antibody. The peroxidase was revealed with $0.05 \% 3,3^{\prime}$-diaminobenzidine (Fluka) in $0.1 \mathrm{~m}$ Tris- $\mathrm{HCl}$ buffer, $\mathrm{pH}$ 7.6 containing $0.01 \% \mathrm{H}_{2} \mathrm{O}_{2}$ (Sigma) and $4 \%$ nickel ammonium sulfate (Carbo-Erba). The sections were then rinsed, first $3 \times 30 \mathrm{~min}$ in PBS, and finally, briefly in distilled water before being processed for light microscopy. They were dehydrated in graded ethanols, defatted in methylcyclohexane, and coverslipped.

Observations and drawings of sections including $L C$. Coronal sections including LC were observed under a light microscope (Reichert) to define, in a first step, the caudal and the rostral limits of the structure. Special care was taken to observe the topology of the LC stained by TH immunohistochemistry so as to establish an accurate anatomical register of all the sections (at intervals of $80 \mu \mathrm{m}$ ) from the different rats.

For each animal, the elements of interest localized in all these sections were drawn using a camera lucida adapted to the microscope. The drawings represented all the TH-positive cell bodies within the LC and anatomical landmarks such as the border of the fourth ventricle $(4 \mathrm{v})$, the vertical symmetric axis of the brain (vsa), and surrounding structures of the LC such as mesencephalic trigeminal nucleus (me5), superior cerebellar peduncle (scp), and the ventral limit of the cerebellar cortex (cer), obtained from adjacent Nissl-stained sections. Both TH-positive cell counting and the topological reconstruction of the mean space of the LC at each anatomical level were made possible by these drawings.

TH-positive cell body parameter determination and calculation. The evolution of three parameters characterizing the noradrenergic cell population of the LC was examined during postnatal development: the number of TH-positive cell bodies, the volume delimited by these perikarya, and the density of TH-positive cells.

For all sections, the mean perikarya diameter obtained by selecting typical TH-positive cells and the surface $\left(S ; \mathrm{mm}^{2}\right)$ of the LC strictly delimited by the TH-positive cells detected by immunohistochemistry were both determined using an image analysis system, including a camera (Pulnix), coupled to the light microscope to transmit the image to a high-resolution monitor, and an adapted software (ANAGRA, P. Platzer, CNRS). The number of counted cells was systematically normalized using the equation of Abercrombie: $N=(n \cdot t) /(t+d)$, where $n$ is the number of these cells, $t$ the thickness of the section, and $d$ the mean diameter of perikarya of the counted cells (Abercrombie, 1946). Considering the diameter of the TH-immunoreactive perikarya, it was verified at each stage that the population of cells was normally distributed (using a Pearson $\chi^{2}$ test of normality) at each anatomical level. A mean diameter could therefore be calculated, and the caudorostral distribution of the diameter led us to determine for each subdivision of the LC a mean diameter applied in the Abercrombie formula. The volume ( $V$; $\left.\mathrm{mm}^{3}\right)$ of the LC was calculated $(V=S \cdot t)$ and the cell density $(D ;$ cell $\left.\mathrm{mm}^{3}\right)$ was estimated $(D=N / V)$. The percentage of the volume occupied by the total TH-positive cell bodies $v\left[v=N \cdot(4 / 3) \pi \cdot(d / 2)^{3}, \mathrm{~mm}^{3}\right]$ versus $V\left(\mathrm{~mm}^{3}\right)$ was also calculated for the whole LC.

The results are expressed as the caudorostral distribution of the mean + SEM of the number of TH-positive cells, the volume in which these cells are contained and the cell density estimated in $80 \mu \mathrm{m}$ intervals from values obtained for 10 - or $20-\mu \mathrm{m}$-thick sections. The mean \pm SEM of the total number of TH-positive cells, the mean \pm SEM of the volume 


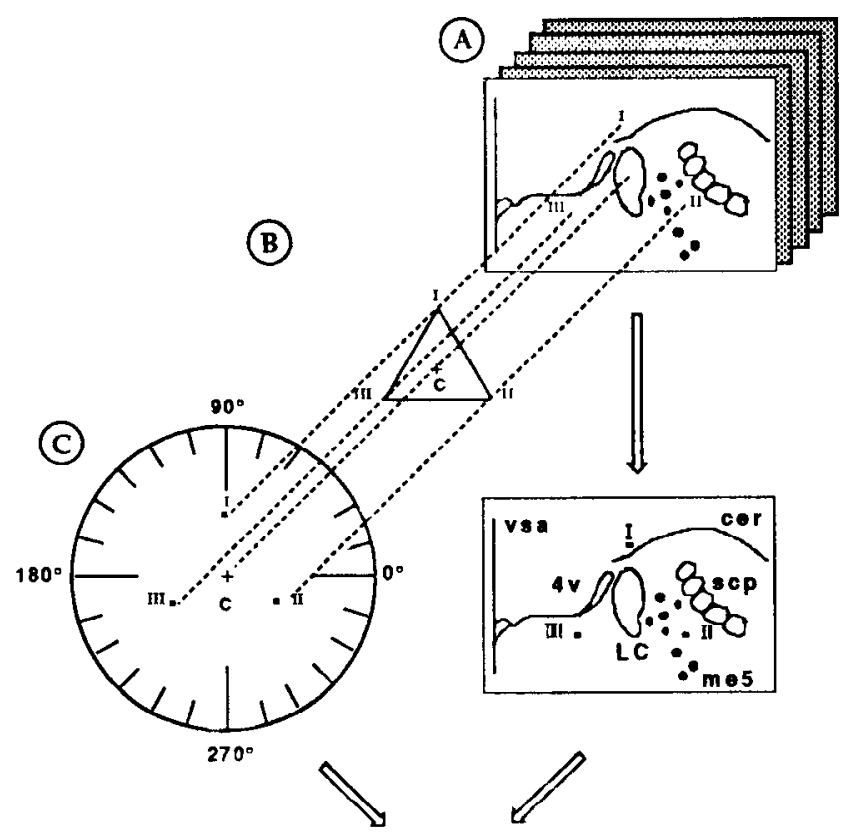

(D)

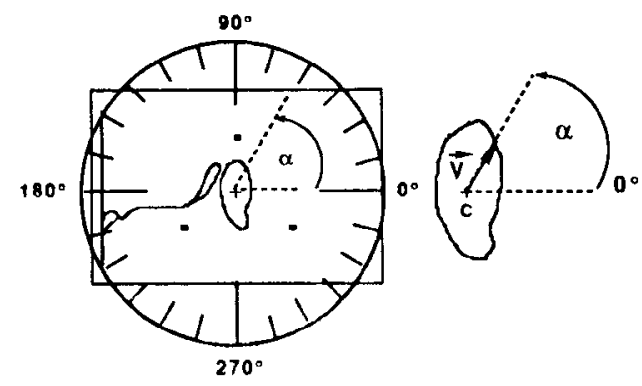

(E)

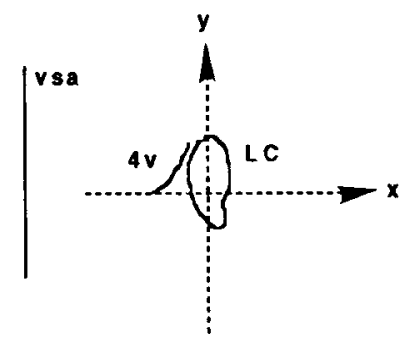

Figure 1. Superimposition of drawings referring to the same anatomical plane and the use of an abacus for the reconstruction of the mean limit of the LC delineated by the TH-expressing cell bodies. $A$, Drawings of a precise anatomical plane of all brains belonging to the same post- containing all these cells and the mean \pm SEM of the cell density in the whole structure and each one of its subregions were also calculated by adding values estimated at each interval of the LC (or part of it).

The statistical analysis of these results was performed using a oneway analysis of variance (ANOVA I), where $n$ is the number of animals, to compare the effect of the postnatal development on the three parameters considered. The comparison between any two developmental stages was made in each of the subregions of the LC using the $95 \%$ Bonferroni simultaneous confidence intervals. An ANOVA I was also used to statistically test, in each age group, the effect of the caudorostral level on each parameter value ( $n$ is the number of all sections analyzed in each group).

Reconstruction of the mean limit of the TH-positive space of the $L C$. The reconstruction of the mean limit of the LC delineated by the THpositive perikarya, the mean border of the fourth ventricle and the mean vertical symetric axis of the brain, was made to follow the evolution of the topological space of the LC during postnatal development, along its caudorostral extent.

A method was developed in our laboratory for reconstructing the mean spacial extent of structures in the plane of the section. This method consists in superimposing one upon the other all the drawings from sections belonging to a same age group and referring to one precise anatomical register. This study was carried out at $160 \mu \mathrm{m}$ intervals. This superimposition was made in such a manner as to keep the best overlap for each anatomical landmark. The best superimposition between each of all piled-up drawings was marked using a reference system formed by three equidistant points (I, II, and III on Fig. 1). The location of the structure in this reference system was determined using an abacus constituted by a trigonometrical circle including the same adjusted ref-

natal stage are superimposed one upon the other, taking into account the best overlap of all anatomical landmarks: the LC, the border of the fourth ventricle $(4 v)$, the vertical symetric axis of the section (vsa), mesencephalic trigeminal nucleus ( $m e 5$ ), superior cerebellar peduncle $(s c p)$, and the ventral limit of the cerebellar cortex (cer). B, A reference system, composed of three equidistant points $(I, I I$, and $I I I)$, was apposed to the piled-up drawings. The center $C$ of the triangle $I, I I, I I I$ was placed within the common area delimited by all piled-up LC. The drawings were then perpendicularly transfixed together at the levels of the three points: $I, I I$, and $I I I . C$, An abacus consisting of a trigonometrical circle on which the angle values between adjacent represented radius are constant. On this circle appears the same reference system as the one defined in $B$, the center of this circle being the same as the center $C$ of the triangle $I, I I, I I I . D$, Quantitative analysis was made on each of the drawings, using the abacus. The marks $I, I I$, and $I I I$ on the drawings were, respectively, superimposed to the points $I, I I$, and $I I I$ on the abacus. On each radius, the polar coordinates of the intersection point between the radius and the structure (defined by its vector and the angle value $\alpha$ of the radius) was recorded. $E$, After transformation of polar coordinates into cartesian coordinates, the mean limit - SEM of the somatic area of the $\mathrm{LC}$ referring to a precise anatomical level was reconstructed into an orthonormalized system.

Figures 2-7. Caudorostral topological reconstruction of the mean space of the LC delineated by the TH-expressing cell bodies and caudorostral distributions of the number of these perikarya, the volume in which these perikarya are clustered and their density. $A$, Quantitative topological reconstruction of the mean TH-positive space of the LC. Coronal parallel slices, from five or six rat brains of the same postnatal age, processed by TH immunocytochemistry and at intervals of $160 \mu \mathrm{m}$, were precisely set in an anatomical register. In a considered plane, the mean limit of the LC delineated by the TH-positive cell bodies has been reconstituted in an orthonormalized system by a method presented in Figure 1. Figures $2-$ 7 report the mean space of the LC and surrounding landmarks for six postnatal stages, respectively: PND4, PND10, PND14, PND21, PND30, and PND42. These reconstructions include the IC represented as its MEAN limit (outside of the border line) - SEM (inside of the border line), the subjective center (full circle) of the LC, the border of the fourth ventricle ( $4 v$ ) and a mark of the vertical symetric axis of the brain ( $v s a$ ). Anatomical level 11 corresponds to the first plane of the anterior LC on its caudorostral axis. Note the progressive disappearance of the ventral anterior region of the LC between PND4 and PND14, the important dorsoventral extent at level 9 between PND4 and PND10 followed by its regression at PND21. The LC exhibits its final shape at PND42. Scale bar, $300 \mu \mathrm{m}$. $B-D$, Caudorostral distribution of the number of TH-expressing cell bodies corrected by Abercrombie formula $(B)$, the volume $\left(\mathrm{mm}^{3}\right)$ containing these cell bodies $(C)$, and the density of these cell bodies $(D)$ (number of cells $/ \mathrm{mm}^{3}$ ), within the subdivisions of the LC: pLC, aLC or daLC and vaLC. Each bar represents the mean + SEM $(n=5-6)$ of these three parameters estimated in $80 \mu \mathrm{m}$ intervals. $E$, Mean diameter $(\mu \mathrm{m})$ of TH-positive cell bodies in the subdivisions of the LC; mean number of TH-positive perikarya, mean volume $\left(\mathrm{mm}^{3}\right)$, and mean density of TH-expressing cell bodies (cell/mm ${ }^{3}$ ), for the total LC and each one of its subdivisions. Cell diameter is expressed as the mean $\pm \mathrm{SD}(n>100)$. Number of TH-positive cell bodies were corrected by Abercrombie formula. Results are expressed as the mean \pm SEM of the parameters $(n=$ number of animals). Percentage of the cell number and percentage of the volume in each subdivision correspond to the percentages of the parameters considered in the subdivision versus the value of the total LC. 


\section{PND4}

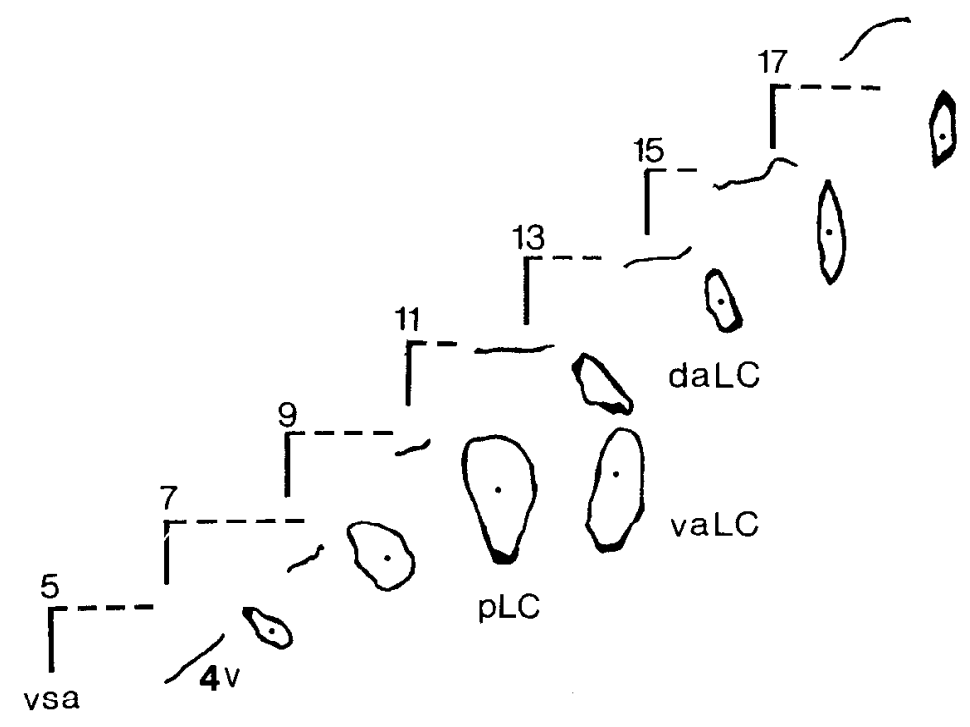

A
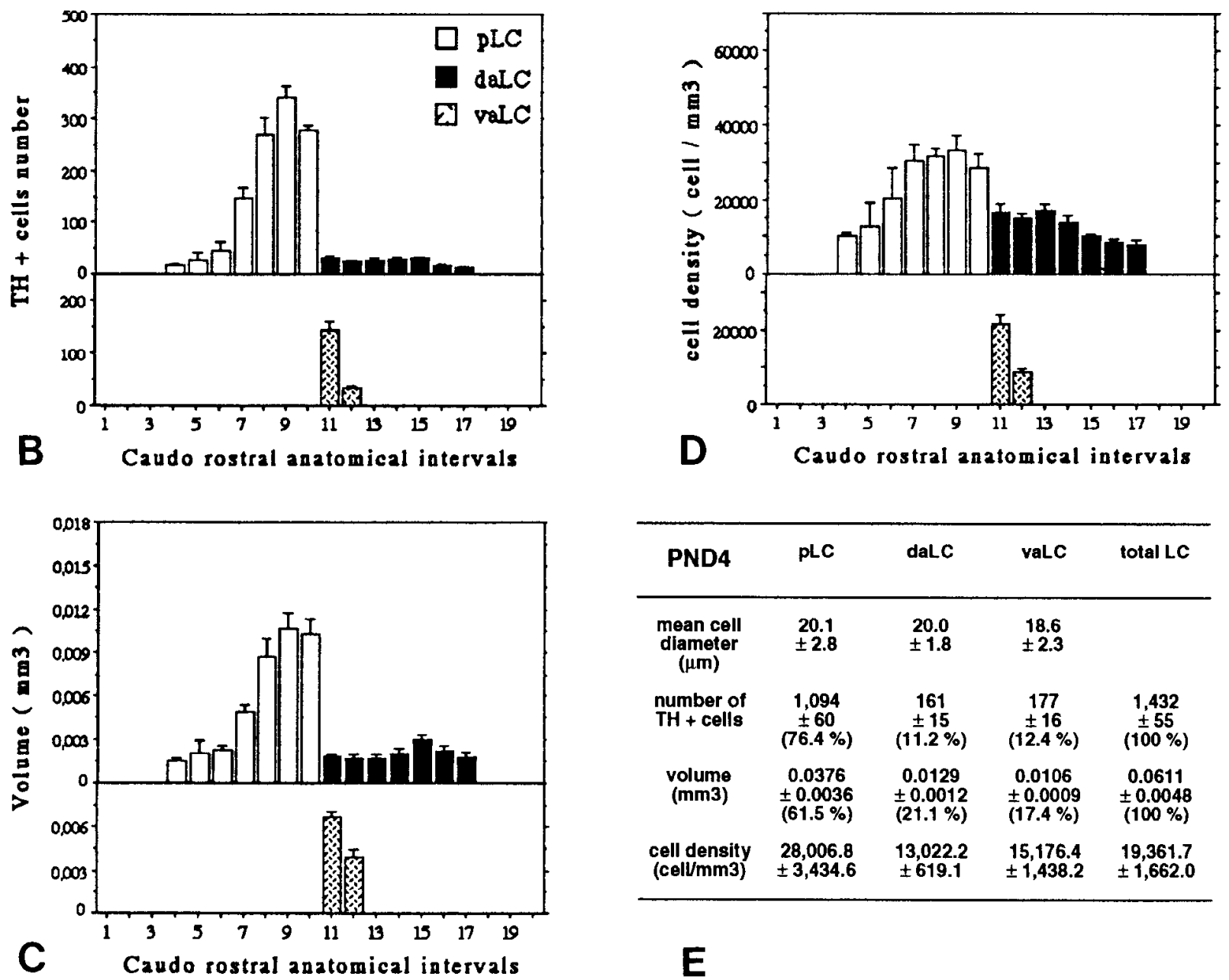

\begin{tabular}{|c|c|c|c|c|}
\hline PND4 & pLC & daLC & vaLC & lotal LC \\
\hline $\begin{array}{l}\text { mean cell } \\
\text { diameter } \\
(\mu \mathrm{m})\end{array}$ & $\begin{array}{r}20.1 \\
\pm 2.8\end{array}$ & $\begin{array}{l}20.0 \\
\pm 1.8\end{array}$ & $\begin{array}{r}18.6 \\
\pm 2.3\end{array}$ & \\
\hline $\begin{array}{l}\text { number of } \\
\mathrm{TH}+\text { cells }\end{array}$ & $\begin{array}{c}1,094 \\
\pm 60 \\
(76.4 \%)\end{array}$ & $\begin{array}{c}161 \\
\pm 15 \\
(11.2 \%)\end{array}$ & $\begin{array}{c}177 \\
\pm 16 \\
(12.4 \%)\end{array}$ & $\begin{array}{c}1,432 \\
\pm 55 \\
(100 \%)\end{array}$ \\
\hline $\begin{array}{c}\text { volume } \\
(\mathbf{m m 3})\end{array}$ & $\begin{array}{c}0.0376 \\
\pm 0.0036 \\
(61.5 \%)\end{array}$ & $\begin{array}{c}0.0129 \\
+0.0012 \\
(21.1 \%)\end{array}$ & $\begin{array}{c}0.0106 \\
\pm 0.0009 \\
(17.4 \%)\end{array}$ & $\begin{array}{c}0.0611 \\
\pm 0.0048 \\
(100 \%)\end{array}$ \\
\hline $\begin{array}{l}\text { cell density } \\
\text { (cell/mm3) }\end{array}$ & $\begin{array}{r}28,006.8 \\
\pm 3,434.6\end{array}$ & $\begin{array}{c}13,022.2 \\
\pm 619.1\end{array}$ & $\begin{array}{r}15,176.4 \\
\pm 1,438.2\end{array}$ & $\begin{array}{r}19,361.7 \\
\pm 1,662.0\end{array}$ \\
\hline
\end{tabular}




\section{PND10}

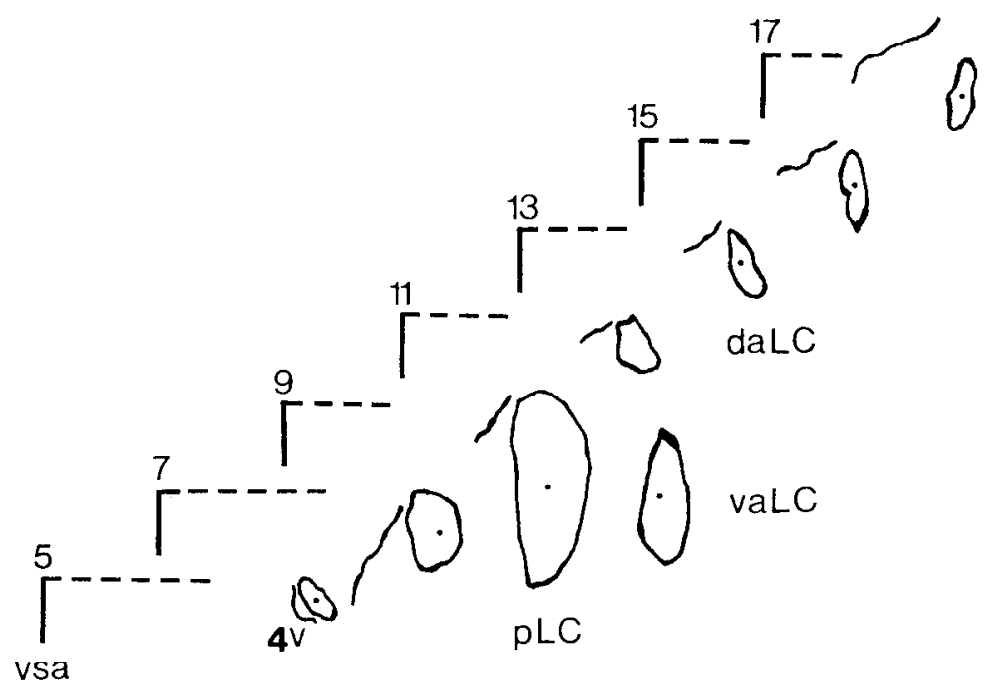

A
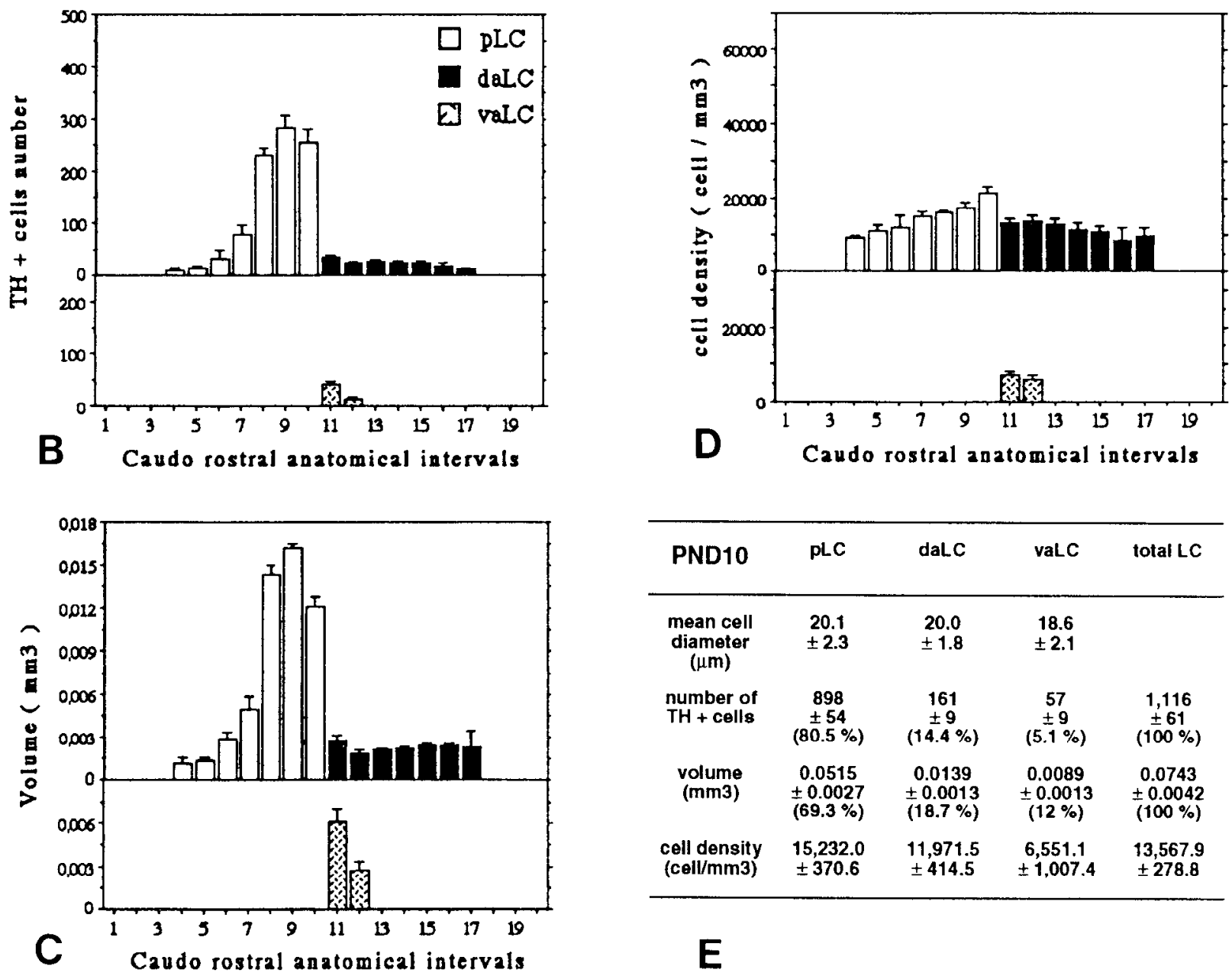

\begin{tabular}{|c|c|c|c|c|}
\hline PND10 & pLC & dalc & vaLC & total LC \\
\hline $\begin{array}{l}\text { mean cell } \\
\text { diameter } \\
(\mu \mathrm{m})\end{array}$ & $\begin{array}{l}20.1 \\
\pm 2.3\end{array}$ & $\begin{array}{r}20.0 \\
\pm 1.8\end{array}$ & $\begin{array}{r}18.6 \\
\pm 2.1\end{array}$ & \\
\hline $\begin{array}{l}\text { number of } \\
\mathrm{TH}+\text { cells }\end{array}$ & $\begin{array}{c}898 \\
\pm 54 \\
(80.5 \%)\end{array}$ & $\begin{array}{c}161 \\
\pm 9 \\
(14.4 \%)\end{array}$ & $\begin{array}{c}57 \\
\pm 9 \\
(5.1 \%)\end{array}$ & $\begin{array}{c}1,116 \\
\pm 61 \\
(100 \%)\end{array}$ \\
\hline $\begin{array}{c}\text { volume } \\
\text { (mm3) }\end{array}$ & $\begin{array}{c}0.0515 \\
\pm 0.0027 \\
(69.3 \%)\end{array}$ & $\begin{array}{c}0.0139 \\
\pm 0.0013 \\
(18.7 \%)\end{array}$ & $\begin{array}{c}0.0089 \\
\pm 0.0013 \\
(12 \%)\end{array}$ & $\begin{array}{c}0.0743 \\
+0.0042 \\
(100 \%)\end{array}$ \\
\hline $\begin{array}{l}\text { cell density } \\
\text { (cell/mm3) }\end{array}$ & $\begin{array}{c}15,232.0 \\
\pm 370.6\end{array}$ & $\begin{array}{c}11,971.5 \\
\pm 414.5\end{array}$ & $\begin{array}{c}6,551.1 \\
\pm 1,007.4\end{array}$ & $\begin{array}{r}13,567.9 \\
+278.8\end{array}$ \\
\hline
\end{tabular}




\section{PND14}

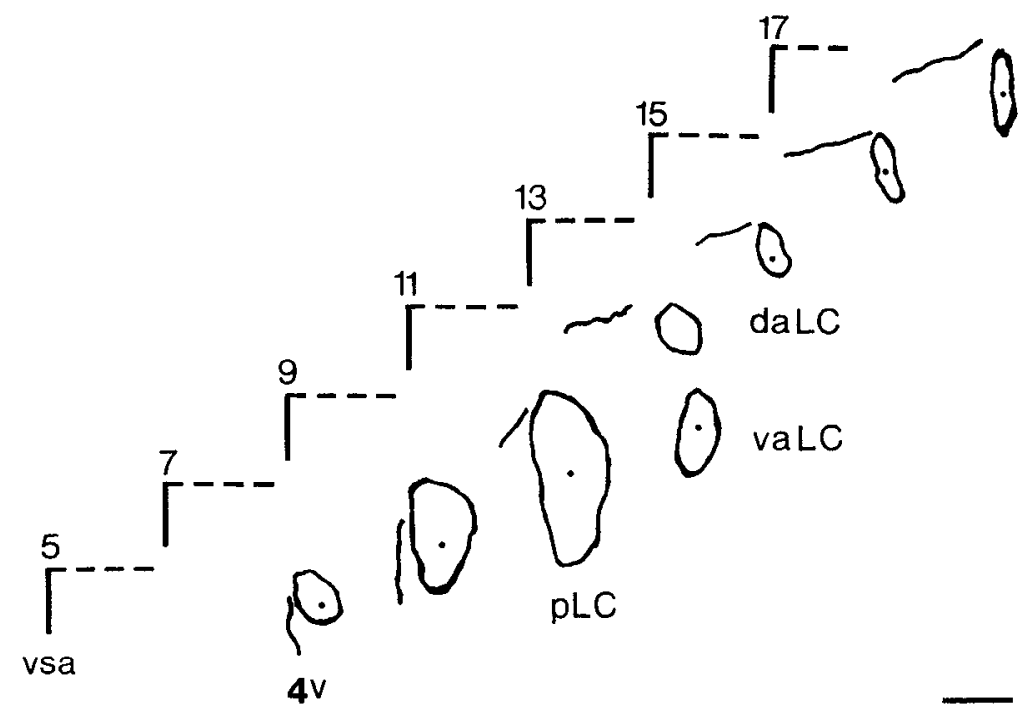

A
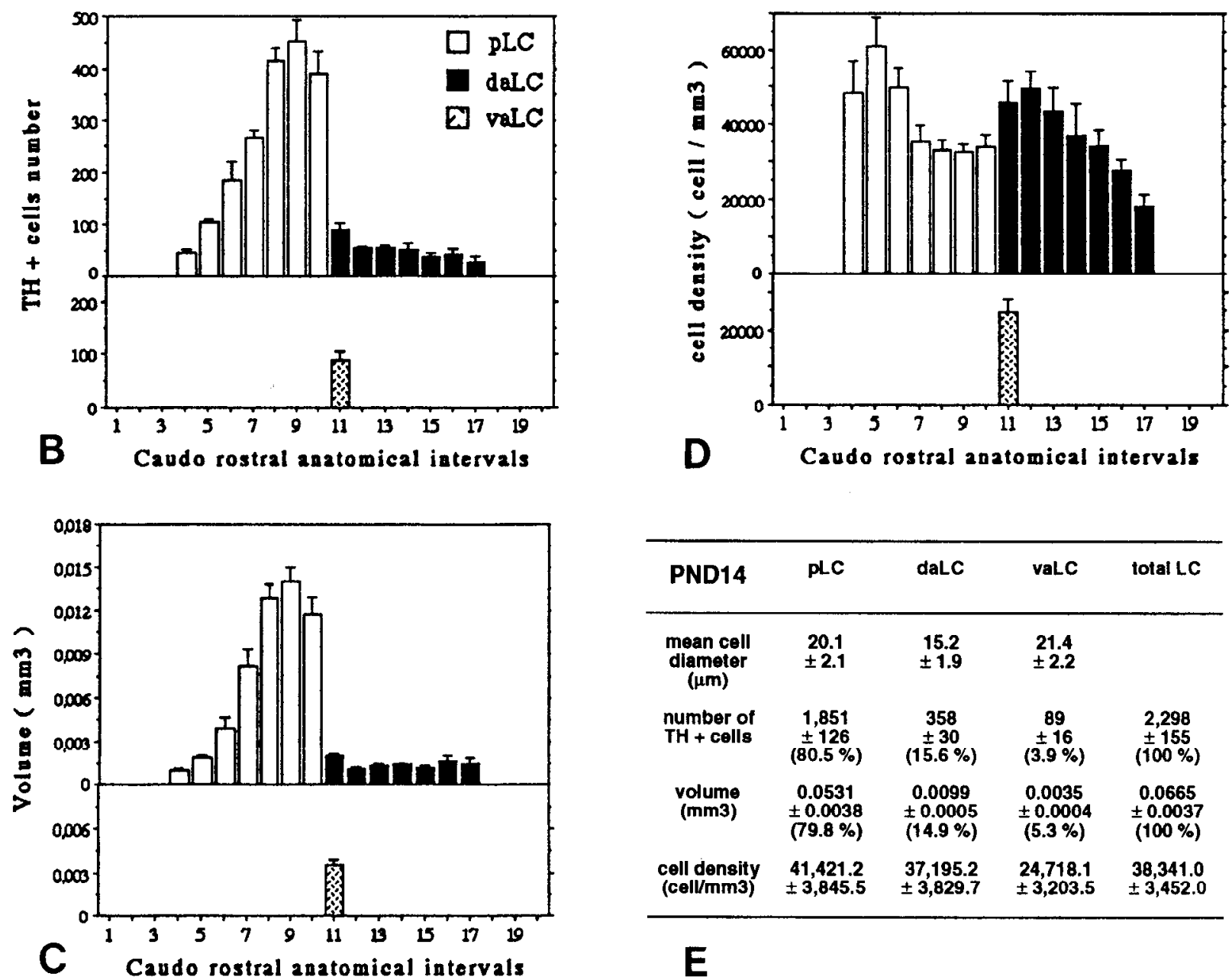

\begin{tabular}{|c|c|c|c|c|}
\hline PND14 & pLC & daLc & vaLC & total LC \\
\hline $\begin{array}{c}\text { mean cell } \\
\text { dlameter } \\
(\mu \mathrm{m})\end{array}$ & $\begin{array}{l}20.1 \\
\pm 2.1\end{array}$ & $\begin{array}{r}15.2 \\
\pm 1.9\end{array}$ & $\begin{array}{r}21.4 \\
\pm 2.2\end{array}$ & \\
\hline $\begin{array}{l}\text { number of } \\
\mathrm{TH}+\text { cells }\end{array}$ & $\begin{array}{c}1,851 \\
\pm 126 \\
(80.5 \%)\end{array}$ & $\begin{array}{c}358 \\
\pm 30 \\
(15.6 \%)\end{array}$ & $\begin{array}{c}89 \\
\pm 16 \\
(3.9 \%)\end{array}$ & $\begin{array}{c}2,298 \\
\pm 155 \\
(100 \%)\end{array}$ \\
\hline $\begin{array}{c}\text { volume } \\
\text { (mm3) }\end{array}$ & $\begin{array}{c}0.0531 \\
\pm 0.0038 \\
(79.8 \%)\end{array}$ & $\begin{array}{c}0.0099 \\
\pm 0.0005 \\
(14.9 \%)\end{array}$ & $\begin{array}{c}0.0035 \\
\pm 0.0004 \\
(5.3 \%)\end{array}$ & $\begin{array}{r}0.0665 \\
\pm 0.0037 \\
(100 \%)\end{array}$ \\
\hline $\begin{array}{l}\text { cell density } \\
\text { (cell/mm3) }\end{array}$ & $\begin{array}{r}41,421.2 \\
\pm 3,845.5\end{array}$ & $\begin{array}{r}37,195.2 \\
\pm 3,829.7\end{array}$ & $\begin{array}{l}24,718.1 \\
\pm 3,203.5\end{array}$ & $\begin{array}{r}38,341.0 \\
\pm 3,452.0\end{array}$ \\
\hline
\end{tabular}

E 


\section{PND21}
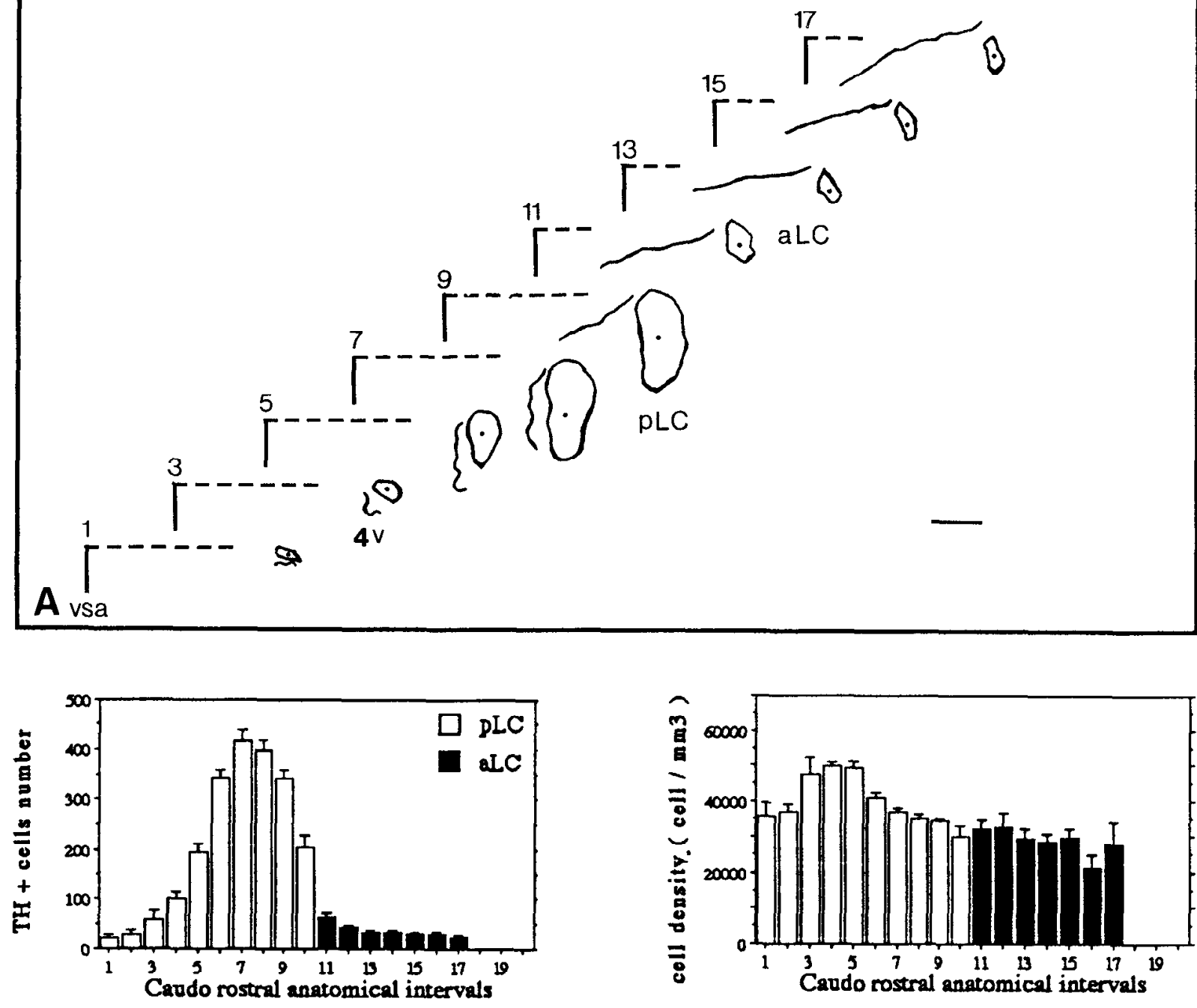

B

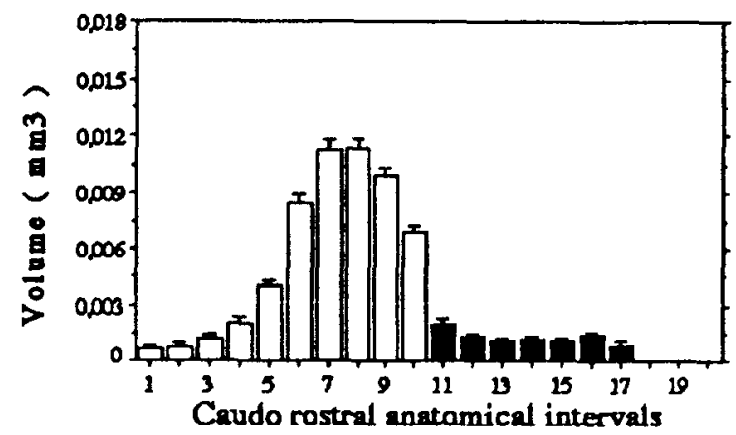

C

\begin{tabular}{|c|c|c|c|}
\hline PND21 & pLC & aLC & total LC \\
\hline $\begin{array}{l}\text { mean cell } \\
\text { diameter } \\
(\mu \mathrm{m})\end{array}$ & $\begin{array}{r}16.2 \\
\pm 2.0\end{array}$ & $\begin{array}{r}16.0 \\
\pm 2.0\end{array}$ & \\
\hline $\begin{array}{l}\text { number of } \\
\mathrm{TH}+\text { cells }\end{array}$ & $\begin{array}{c}2,083 \\
\pm 102 \\
(90.7 \%)\end{array}$ & $\begin{array}{c}214 \\
\pm 29 \\
(9.3 \%)\end{array}$ & $\begin{array}{c}2,297 \\
\pm 92 \\
(100 \%)\end{array}$ \\
\hline $\begin{array}{l}\text { volume } \\
\text { (mm3) }\end{array}$ & $\begin{array}{c}0.0558 \\
\pm 0.0024 \\
(88.6 \%)\end{array}$ & $\begin{array}{c}0.0072 \\
\pm 0.0013 \\
(11.4 \%)\end{array}$ & $\begin{array}{c}0.0630 \\
\pm 0.0016 \\
(100 \%)\end{array}$ \\
\hline $\begin{array}{l}\text { cell density } \\
\text { (cell/mm3) }\end{array}$ & $\begin{array}{l}39,750.7 \\
\pm 791.5\end{array}$ & $\begin{array}{r}31,111.1 \\
\pm 2,794.5\end{array}$ & $\begin{array}{r}36,221.8 \\
\pm 1,446.4\end{array}$ \\
\hline
\end{tabular}

E 


\section{PND30}
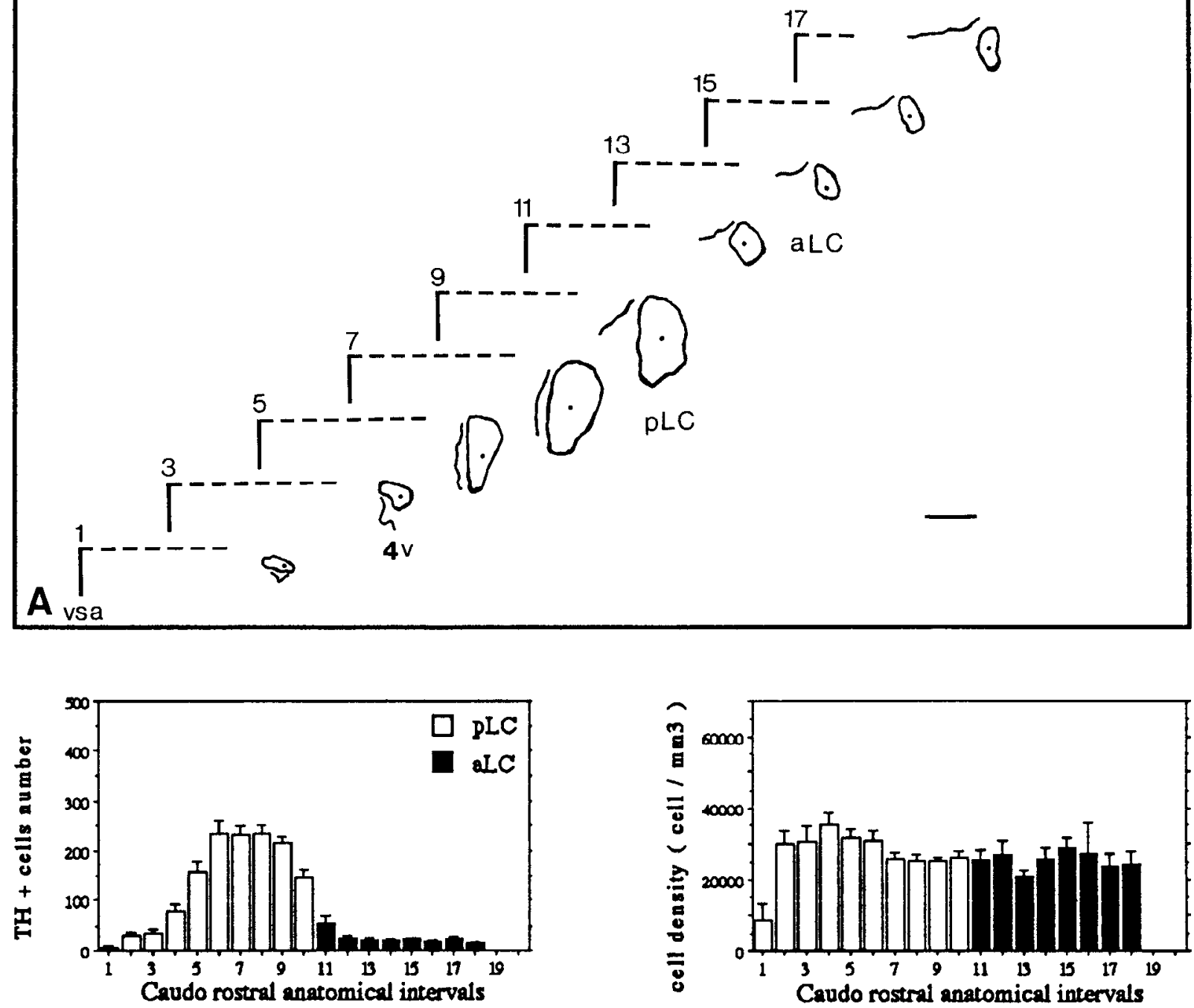

B

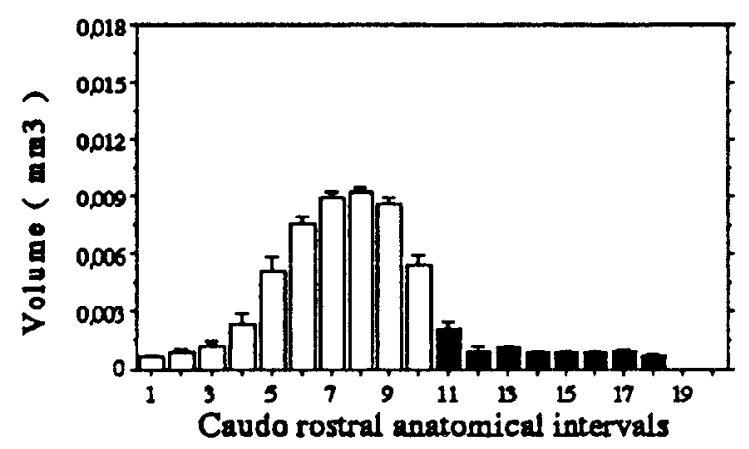

\begin{tabular}{|c|c|c|c|}
\hline PND30 & pLC & aLC & total LC \\
\hline $\begin{array}{c}\text { mean cell } \\
\text { diameter } \\
\text { ( } \mu \mathrm{m})\end{array}$ & $\begin{array}{r}15.0 \\
\pm 1.9\end{array}$ & $\begin{array}{r}15.0 \\
\pm 1.7\end{array}$ & \\
\hline $\begin{array}{l}\text { number of } \\
\text { TH + cells }\end{array}$ & $\begin{array}{c}1,354 \\
\pm 65 \\
(86.6 \%)\end{array}$ & $\begin{array}{c}209 \\
\pm 19 \\
(13.4 \%)\end{array}$ & $\begin{array}{c}1,563 \\
\pm 61 \\
(100 \%)\end{array}$ \\
\hline $\begin{array}{l}\text { volume } \\
\text { (mm3) }\end{array}$ & $\begin{array}{c}0.0495 \\
\pm 0.0016 \\
(85.8 \%)\end{array}$ & $\begin{array}{c}0.0082 \\
\pm 0.0008 \\
(14.2 \%)\end{array}$ & $\begin{array}{c}0.0577 \\
\pm 0.0016 \\
(100 \%)\end{array}$ \\
\hline $\begin{array}{l}\text { cell density } \\
\text { (celv/mm3) }\end{array}$ & $\begin{array}{r}28,513.3 \\
\pm 2,126.2\end{array}$ & $\begin{array}{r}25,563.5 \\
\pm 1,021.5\end{array}$ & $\begin{array}{r}27,086.5 \\
\pm 1,286.5\end{array}$ \\
\hline
\end{tabular}

C

E

Figure 6. 

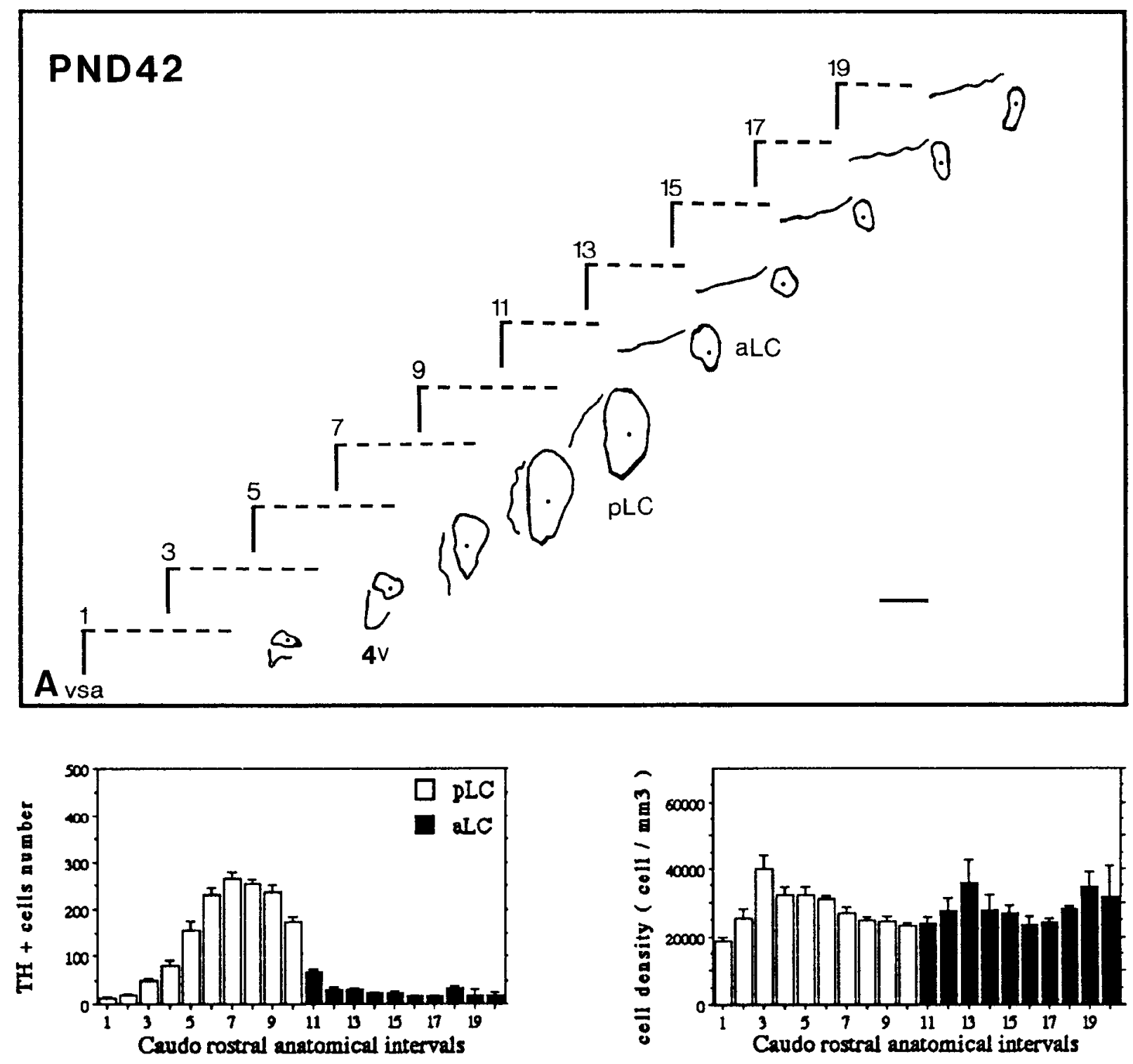

B

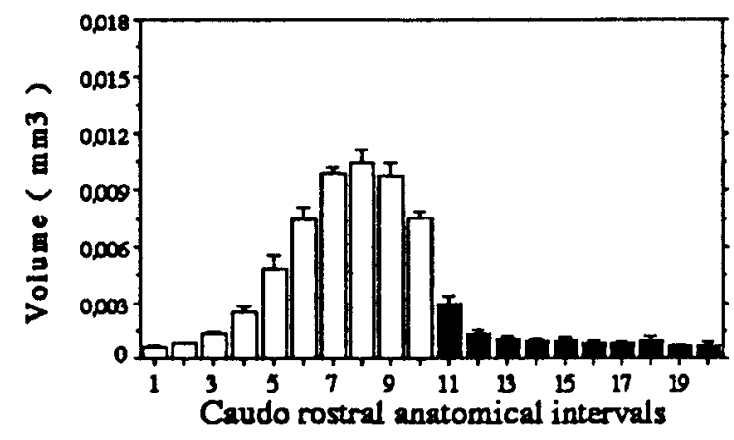

\begin{tabular}{cccc}
\hline PND42 & pLC & aLC & total LC \\
\hline $\begin{array}{c}\text { mean cell } \\
\text { diameter } \\
(\mu \mathrm{m})\end{array}$ & 14.4 & 14.4 & \\
$\begin{array}{c}\text { number of } \\
\text { TH + cells }\end{array}$ & $\begin{array}{c}1,477 \\
\pm 37\end{array}$ & 251 & \\
& $(85.5 \%)$ & $(14.5 \%)$ & $(100 \%)$ \\
volume & 0.0551 & 0.0102 & 0.0653 \\
(mm3) & \pm 0.0022 & \pm 0.0007 & \pm 0.0028 \\
& $(84.4 \%)$ & $(15.6 \%)$ & $(100 \%)$ \\
cell density & $28,373.5$ & $27,372.5$ & $27,981.0$ \\
(cell/mm3) & \pm 569.9 & $\pm 2,178.2$ & $\pm 1,213.0$ \\
\hline
\end{tabular}

C 
erence system. Angles between consecutive represented radius were constant on the abacus $\left(15^{\circ}\right.$ apart). Details of the superimposition of the drawings and the use of the abacus are schematically represented in Figure 1. To measure the polar coordinates of the structure each drawing was then apposed to the abacus. After transformations of the polar coordinates into cartesian coordinates, the mean limit - SEM of the structure was then reconstructed in an orthonormalized system by linking the mean value obtained on consecutive radius.

\section{Results}

Postnatal evolution of the phenotypic characters of $T H$-expressing cells along the caudorostral extent of the $L C$ The cellular phenotypic parameters characterizing the TH expression in the LC were examined along the caudorostral extent of the structure at six postnatal stages: PND4 (Fig. 2), PND10 (Fig. 3), PND14 (Fig. 4), PND21 (Fig. 5), PND30 (Fig. 6), and PND42 (Fig. 7). For each $160 \mu \mathrm{m}$, the mean limit of the space of the LC delineated by the TH-expressing perikarya was quantitatively reconstructed. The number of TH-positive cell bodies detected by immunohistochemistry, the volume delimited by these perikarya and the cell density were evaluated in $80 \mu \mathrm{m}$ intervals within different subdivisions of the LC: posterior LC $(\mathrm{pLC})$, dorsal anterior $\mathrm{LC}(\mathrm{daLC})$ or anterior $\mathrm{LC}(\mathrm{aLC})$ and ventral anterior LC (vaLC) when it was observable.

Postnatal evolution of the topological space delimited by the $T H$-expressing cell bodies within the $L C$

Using the method of the superimposition of drawings referring to a precise anatomical level in an age group, the evolution during postnatal development of the topological organization of the TH-expressing cell bodies within the LC was established at intervals of $160 \mu \mathrm{m}$.

In each considered developmental stage, these reconstructions exhibited a high constance of the space of the LC (Figs. 2A-7A). Indeed, the SEMs of both this space and surrounding anatomical landmarks were very low $(<10 \%)$ in the different anatomical levels within each age group.

From PND4 to PND14, the observations of the space occupied by the TH immunopositive cells revealed a clear division into dorsal and ventral parts in the middle of the caudorostral extent of the LC (level 11, Figs. $2 A-4 A, 8 A, B$ ). The analysis of the caudorostral distribution of the TH positive cells and the spaces delineated by these cells allowed to clearly divide this structure into a posterior, an anterior dorsal, and an anterior ventral subregion. From PND21 through PND42, such an anatomical division in the anterior $\mathrm{LC}$ was no longer observable (level 11, Figs. $5 A-7 A, 8 C, D$ ). In this study, and for all age groups, anatomical level 11 represents the first rostral plane of the LC on its caudorostral axis. At PND42, it corresponds to IA: $-0.72 \mathrm{~mm}$ in Paxinos and Watson's stereotaxic atlas (1986).

During postnatal development, an increase in the distance between the center of the LC and the vertical symetric axis of the brain was noticed, the $\mathrm{LC}$ being then progressively shifted into a more lateral position (Figs. $2 A-7 A$ ).

\section{Postnatal evolution of the number of TH-expressing cells}

At each developmental stage, the number of TH-expressing cells was significantly distributed $(p<0.0001$, ANOVA I, $65<$ number of sections $<113$ ) along the caudorostral axis of the structure (Figs. $2 B-7 B$ ). The pLC represented $76-91 \%$ (Figs. $2 E-7 E$ ) of the TH-expressing cells enumerated in the total LC, validating the division of the LC into a large posterior and a small anterior subregion.
The TH-expressing cells enumerated in the total LC at PND14 and PND21 were $33 \%$ more than that at PND42 (Fig. 9). The transient enhancement of this parameter at these two stages occurred within the pLC and the daLC at PND14, whereas it only appeared within the pLC at PND21 (Fig. 9).

Compared to PND42, the increases in the TH-expressing cell number were localized in the pLC on levels $8-10$ (Figs. $4 B, 7 B$ ) and 6-9 (Figs. 5B, 7B) at PND14 and PND21, respectively. In the daLC the enhancement at PND14 was observed on levels 11-16 (Figs. 4B, 7B).

At PND21 $344 \pm 40$ Nissl-stained neurons have been enumerated in the daLC, exactly in the space delimited by the THimmunoreactive neurons.

\section{Postnatal evolution of the volume delimited by the TH-expressing cell bodies}

At each developmental stage, the volume delimited by the THexpressing cells was significantly distributed $(p<0.0001$, ANOVA I, $65<$ number of sections $<113$ ) along the caudorostral axis of the structure (Figs. $2 C-7 C$ ). The pLC represented 61$88 \%$ (Figs. $2 E-7 E$ ) of the total LC volume, which also validated the division of the $\mathrm{LC}$ into a large posterior and a small anterior subregion.

Although the postnatal development of the volume was almost constant in the total LC, the evolution of this parameter differed in the subregions of the structure (Fig. 9). The progressive enhancement of the $\mathrm{pLC}$ was concomitant to the regression of the val.C (Fig. 9), and no variation of the sum of the vaLC, and pLC volumes was observed during the postnatal development ( $p<0.073$, ANOVA I; Fig. 10).

It is interesting to note that, at PND14, the volume within the pLC reached values on levels $8-10$, which were never observed at the adult stage at the same anatomical intervals (Figs. $4 B, 7 B)$.

\section{Postnatal evolution of the density of the TH-expressing cell bodies}

The caudorostral distribution of the cell density was affected by the postnatal development. The cell density was distributed from PND4 to PND21 (Figs. 2D-5D; $p<0.0001$, ANOVA I, $65<$ number of sections < 97). Beyond PND21, it was less distributed [PND30 (Fig. 6D), $p<0.096$, ANOVA I, number of sections = 104; PND42 (Fig. $7 D$ ), $p<0.001$, ANOVA I, number of sections $=113$ ].

In the total $\mathrm{LC}$ and in the pLC, the cell density was greater at PND14 and PND21 than at the other stages (Fig. 9). In the daLC and the vaLC, the peak of the cell density was observed at PND14 (Fig. 9).

At each developmental stage, the volume strictly occupied by the TH-expressing perikarya in the volume delimited by these perikarya was very weak and never more than $14 \%$ (Fig. 11).

\section{Comparison of the LC space at level 9 at PND14, PND21,} and PND42

The superimposition of the spaces of the LC delimited by the $\mathrm{TH}$-expressing cell bodies was carried out taking into consideration the superimposition of the lateral cxtremity of the fourth ventricle and keeping the parallelism of the vertical symetric axis between the different stages considered. These superimpositions revealed a ventrolateral enlargement of the space on level 9 at PND14 as compared to PND42 (Fig. 12A), whereas 

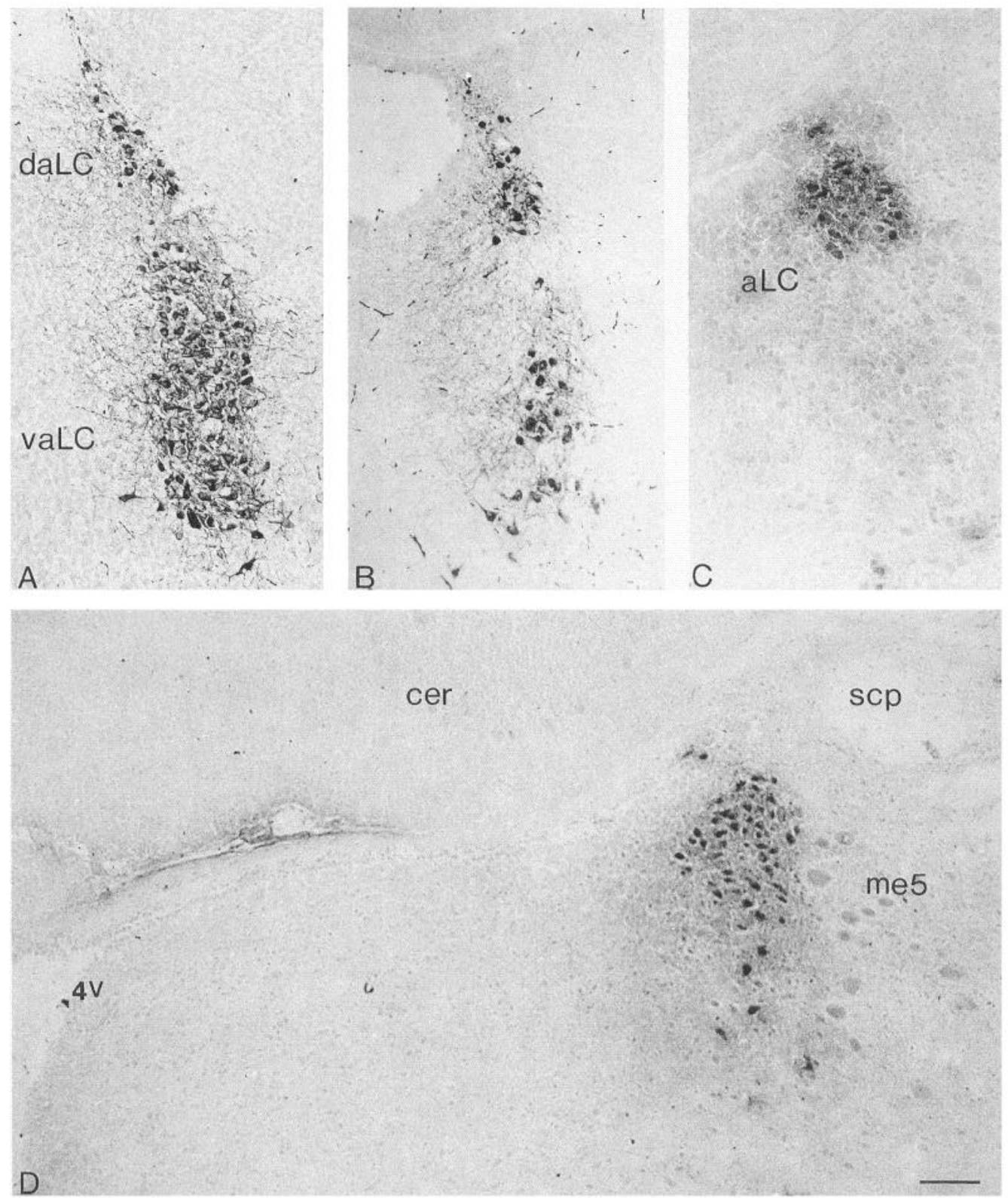

Figure 8. TH-immunoreactive cell bodies revealed in the anterior LC (level 11), using the peroxidase-antiperoxidase method. $A$ and $B$, Coronal sections realized through the LC at PND4 $(A)$ and PND10 $(B)$, obtained from tissue fixed by immersion in a cold $4 \%$ paraformaldehyde, $0.2 \%$ picric acid solution and processed by TH immunohistochemistry. At these developmental stages, the LC exhibits an unquestionable division into a small dorsal group $(\mathrm{daLC})$ and a ventral group $(\mathrm{vaLC})$. The daLC is localized at the proximity of the fourth ventricle. Note the reduction in the vaLC between PND4 and PND10. $C$ and $D$, Coronal section made throughout the LC at PND21 $(C)$ and PND42 (D), obtained from fresh frozen tissue and postfixed in a $4 \%$ paraformaldehyde solution before processing by TH immunohistochemistry. At these stages, the LC is constituted by a cell group located near the fourth ventricle. The vaLC was not detected at PND21 $(C)$ and beyond $(D)$. At PND42, level $11(D)$ corresponds to IA: $-0.72 \mathrm{~mm}$ in Paxinos and Watson's stereotaxic atlas (1986). At PND42 (D), anatomical landmarks such as the fourth ventricle (4v), the mesencephalic trigeminal nucleus $(m e 5)$, the ventral limit of the cerebellar cortex ( $c e r)$, and the superior cerebellar peduncle ( $s c p)$ are also indicated. The left limit of the microphotograph corresponds to the vertical symetric axis of the brain. Scale bar, $100 \mu \mathrm{m}$.

no modification of this space was observed between PND21 and PND42 (Fig. 12B).

\section{Discussion}

A plasticity of the phenotypic characteristics of TH expression in the LC during postnatal development has already been hypothesized on the basis of a biochemical study showing that the TH levels progressively increased during postnatal development from birth to adulthood (Zyzek et al., 1990). This approach to the developmental evolution of the TH steady state within the
LC did not take into account the anatomical organization of cells involved in the regulation of this protein. The present work was devoted to the examination of the postnatal evolution of quantitatively determined cellular parameters necessary to the precise phenotypic characterization of TH expression in this structure: the mean number of the TH-expressing perikarya, the mean limit of the space delineated by these cell bodies, the mean volume of the structure the TH-positive perikarya delimited and their density. These parameters were carefully examined along the caudorostral extent of the structure. 
TH expressing cell bodies
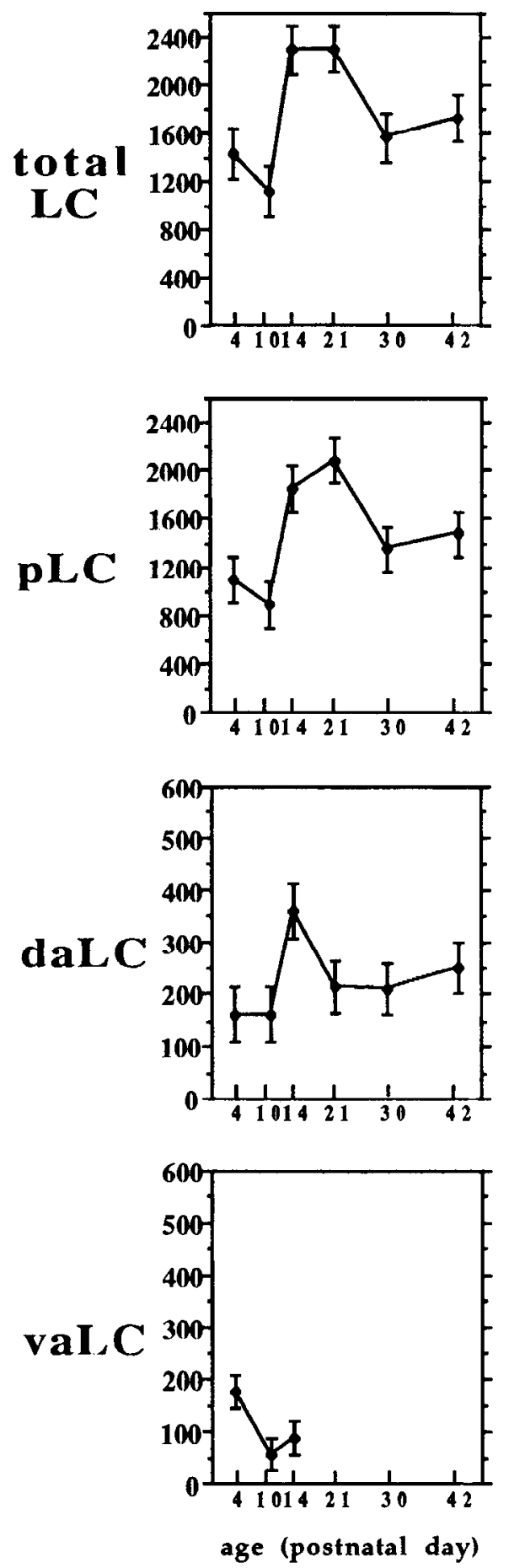

volume

$(\mathrm{mm} 3)$
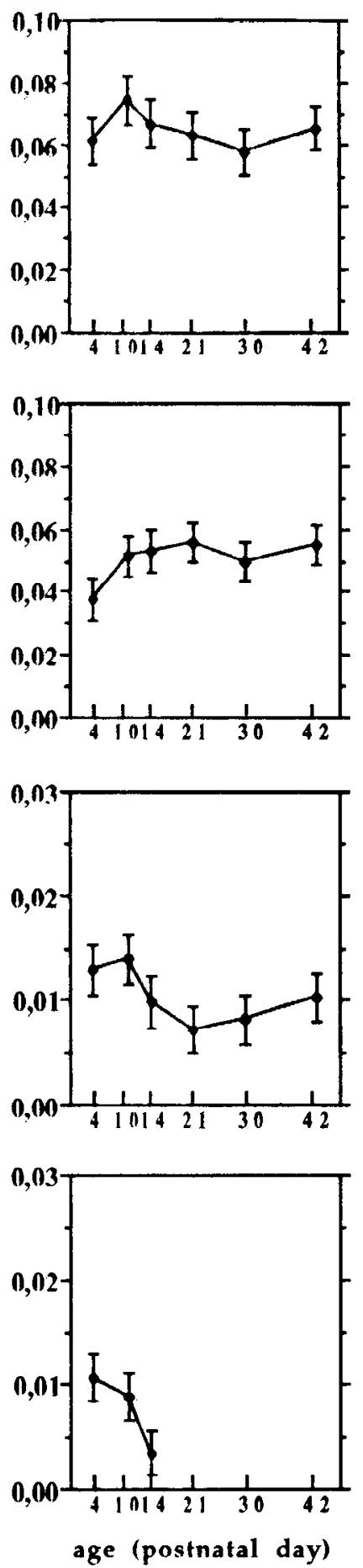

cell density (cell/mm3)
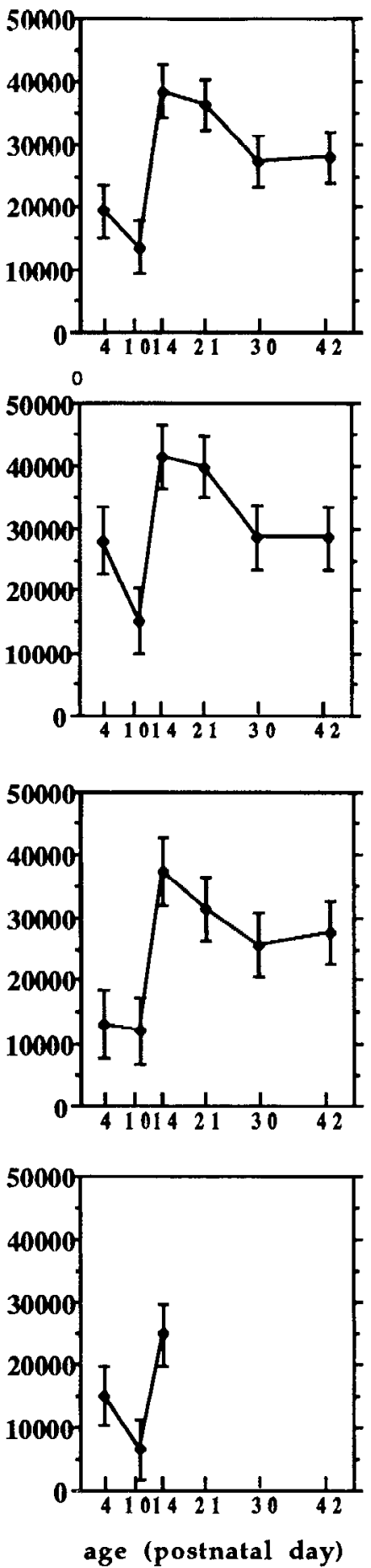

Figure 9. Statistical analysis of the postnatal evolution of the parameters characterizing the TH-immunopositive cell bodies in the whole LC and each one of its subregions. Parameters, for each age, are expressed as the mean \pm the $95 \%$ Bonferroni confidence interval. The effect of development on these parameters is studied using a one-way ANOVA. Significant difference $(p<0.05)$ between two age groups can be considered when their respective $95 \%$ Bonferroni confidence intervals do not overlap. For the total $L C$, the postnatal development affects the number of TH-positive cell bodies $(p<0.0001)$, the volume delimited by these cell bodies $(p<0.024)$ and the cell density $(p<0.0001)$. Note the important increase in the number of TH-expressing cells at PND14 and PND21. For the $p L C$, the postnatal development affects the number of TH-positive cell bodies ( $p$ $<0.0001)$, the volume delimited by these cell bodies $(p<0.001)$ and the cell density $(p<0.0001)$. For the daLC, from PND4 to PND14 and from PND2 1 to PND42 the values for the daLC and aLC are reported, respectively. Postnatal development affects the number of TH-positive cell bodies $(p<0.0001)$, the volume delimited by these cell bodies $(p<0.0001)$ and the cell density $(p<0.0001)$. For the vaLC, the postnatal development affects the number of TH-positive cell bodies $(p<0.0001)$, the volume delimited by these cell bodies $(p<0.001)$ and the cell density $(p<0.0001)$. 


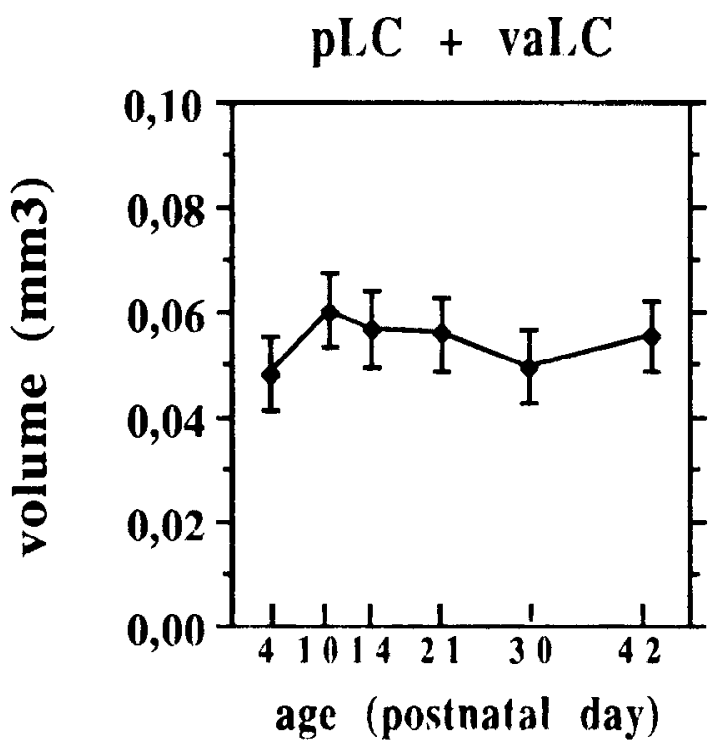

Figure 10. Postnatal evolution of the volume circumscribed by the TH-expressing cell bodies, when $\mathrm{pLC}$ and vaLC volumes are grouped together. At PND21-PND42, only the pLC was considered since the vaLC was no more detectable at these developmental stages. The volume is expressed in the same manner as the one of Figure 9. Postnatal development does not affect the volume of the sum of these two subdivisions $(p<0.073)$.

\section{Methodological considerations}

The topological reconstruction of the space containing the THimmunopositive cell bodies of the LC has been established in the plane of the section. To attain an undistorted reconstruction of the structure at each anatomical level, indispensable precautions were followed: several classical anatomical landmarks were drawn and the orientation of the drawings amongst after their superimposition was marked using a constant reference system. The results indicated that the variability for each anatomical
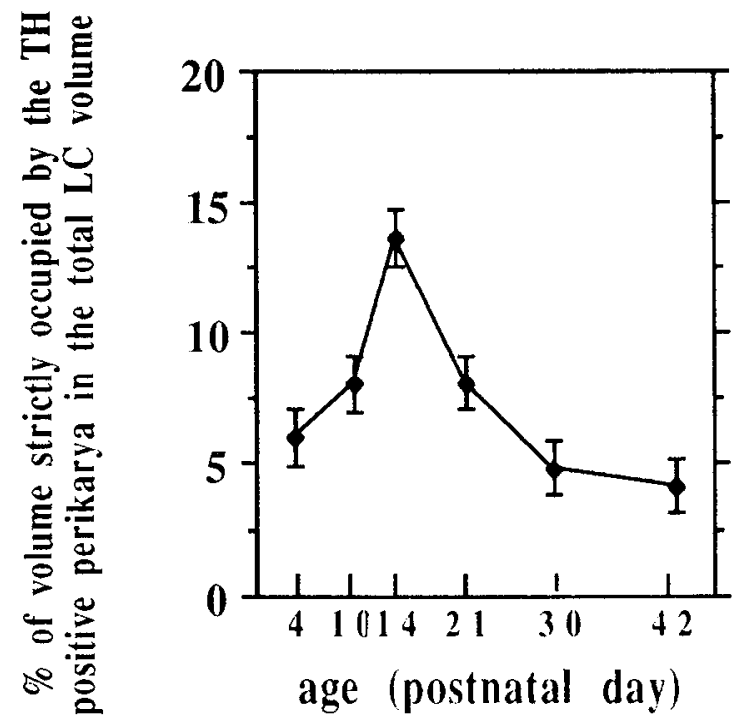

Figure 11. Postnatal evolution of the percentage of the total volume occupied by the TH positive perikarya versus the total LC volume delineated by these cell bodies. This parameter, for each age, is expressed in the same way as those of Figure 2. Postnatal development affects this ratio $(p<0.0001)$.
A

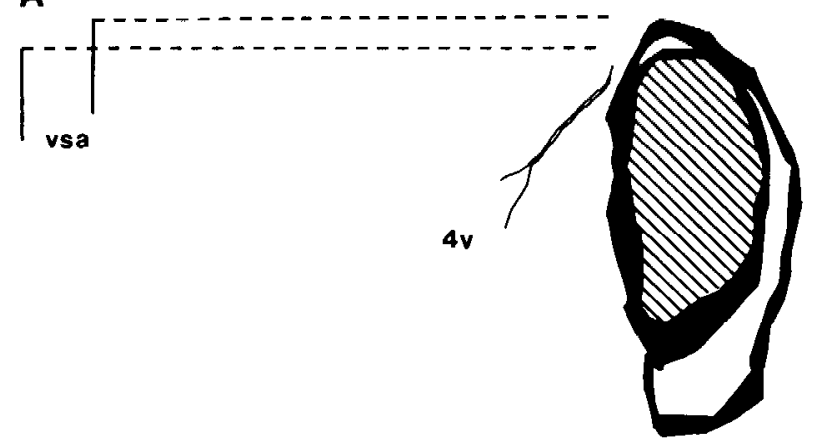

B

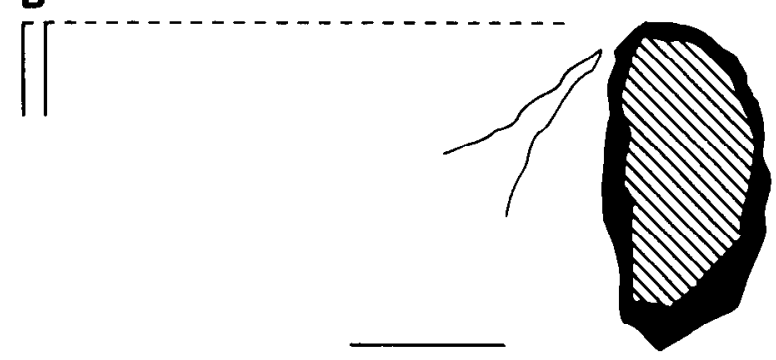

Figure 12. Superimposition of the mean space of the LC on the anatomical level 9 between PND14 and PND42 $(A)$ and between PND21 and PND42 $(B)$. The overlap of the lateral extremity of the fourth ventricle and the parallelism of the vertical axis of the brains were taken into consideration in superimposition of the LC. The mean limit \pm SEM (thickness of the dark space) of the topological space for each stage of the LC is represented. In $A$ and $B$, PND42 level 9 is represented over the PND14 and the PND21 level 9, respectively, and the "common" area for the three stages has been hatched. Note the reducing of the ventrolateral tip of the LC at this anatomical level between PND14 and PND42, and the perfect overlap of the limits of the LC somatic area at this same level between PND21 and PND42. The mean number $N$ of TH-immunoreactive cell bodies corrected by the Abercrombie formula and the density $\left(\mathrm{N} / \mathrm{mm}^{3}\right)$ of these cells at this anatomical level were, respectively: 57 cells and 32,395 cells $/ \mathrm{mm}^{3}$ for PND14, 43 cells and 34,466 cells $/ \mathrm{mm}^{3}$ for PND21, and 30 cells and 24,531 cells $/ \mathrm{mm}^{3}$ for PND42. Scale bar, $300 \mu \mathrm{m}$.

landmark was very weak, which highlights several concerns (1) at each stage, a high reproducibility of the section plane between brains of the same stage was obtained since SEMs of the LC were very weak in dorsal and ventral as well as in median and lateral orientations. The method we used for these topological reconstructions can be then considered as adapted to accurately reproducing the observed images. (2) Comparisons between different stages could be proposed since dorsoventral deviations of the sectioning angle have been limited thanks to the different precautions taken during freezing and before cutting the brains.

\section{General evolution of the LC cell body organization during the postnatal development}

As already described in anatomical as well as in biochemical investigations (Loughlin et al., 1986; Debure et al., 1992; Blanchard et al., 1993; Schmitt et al., 1993) an anatomical dichotomy of the LC into a posterior and an anterior subdivision was observed at all stages of the postnatal development.

The study at the early postnatal development, from PND4 to PND14, allowed us to separate the anterior LC into two parts: the dorsal anterior $\mathrm{LC}(\mathrm{daLC})$ and the ventral anterior $\mathrm{LC}(\mathrm{vaLC})$, 
the latter being no longer observable beyond PND14. The daLC was supposed to constitute in the latest stages of postnatal development the anterior region of the LC such as it appeared in the adult rat, considering first and principally its anatomical position and, second, the proportions of the number of THpositive perikarya as well as the volume in which they were contained relative to the entire LC. Taking into account the maturation of the vaLC, the evolution of the volume analysis revealed that when the vaLC and the pLC were grouped together, a good constance of this parameter was observed, underscoring the possibility that the vaLC and the pLC may constitute a single anatomical entity. The possible shift of the pLC and the vaLC within the brainstem could result to the deep remodeling that the whole brain undergoes during postnatal development as illustrated by the increase in the distance we observed between the LC and the vertical symetric axis of the brain and as already suggested by Sievers et al. (1981). However, all these remodelings of the coeruleal cell population organization did not seem to be randomly established, considering that the quantitative topological reconstruction of the structure, level by level along its caudorostral axis, exhibited a very low variability for each postnatal stage considered. These results suggest that during postnatal development the position of the coeruleal $\mathrm{TH}$-expressing perikarya might be imposed by genetic and/or epigenetic determinism. Furthermore, concomitant to these reorganizations, the volume in which the TH-positive cell bodies of the total LC were clustered remained stable during postnatal development. The isovolumic transformations of the LC would imply that the cellular elements (afferents or vicinal cells) involved in the cellular expression of $\mathrm{TH}$ could follow a remodeling as the one observed.

\section{TH phenotypic plasticity in the cell bodies: evidence for organized subset of transient TH-expressing cells}

Modulations of the functions in which the LC is involved could result from modifications in the phenotypic characteristics of TH expression in these neurons. During postnatal development, changes of TH expression in the LC could result in part from the fluctuation in the number of the TH-containing cells. Indeed, at PND14 and PND21 a 33\% increase in the TH-positive cell number was found as compared to PND42. Such newly THimmunopositive cells would be transient TH-expressing cells since they were not detected at PND10 and were not observed at PND30 and beyond. It did not seem probable that this transient enhancement of the number of TH-expressing cells resulted in a neuronal division since the peak of neuronal mitotic activity in LC precursors has been dated at the embryonic day 12.5 (Lauder and Bloom, 1974). Different molecular forms of $\mathrm{TH}$ protein in central dopaminergic and noradrenergic neurons have been suggested (Joh and Reis, 1975; Pickel et al., 1975) and this observation has been strengthened by the selectivity of different anti-TH antibodies for these catecholaminergic cell population, notably during development (Specht et al., 1981; Verney et al., 1982). In our experimental conditions, the antibody chosen recognized the adult form of $\mathrm{TH}$ protein in the noradrenergic neurons of the LC since we have counted an equivalent number of TH-immunoreactive cells to the number of dopamine- $\beta$-hydroxylase-containing cells reported by Swanson (1976) and Luque et al. (1992) in the LC proper (already reported by Gagne et al., 1990; Chamba et al., 1991; Debure et al., 1992). We can conclude that this $\mathrm{TH}$ protein form was transiently present at detectable levels in a particular subset of neurons.

The caudorostral distribution analysis of these cells revealed different localizations of transient TH-expressing cells at PND14 and PND21. They were observed in the posterior and the dorsal anterior LC at PND14 whereas they were only detected in the posterior LC at PND21. Furthermore, the enhancement of the cell number in the pLC was concomitant to an increase in the volume delineated by the TH-expressing cell bodies at PND14 but not at PND21 as compared to the volume of comparable anatomical levels observed at PND42. The transient enhancement of the TH-expressing cell number, which would not be a randomly distributed but would correspond to an organized and physiologically controled phenomenon, incited us to seek evidence for a possible localization of these transient TH-expressing cells.

The conjoint analysis of the quantitative topological reconstruction of the space of the LC delineated by the TH-containing cells and the density of these cells suggest the existence of three different pools of transient TH-expressing cells. The first one would be seated in the dorsal anterior LC, the two others differentially localized in the posterior LC.

Apparently, between PND14 and PND21, 40\% of the cells located within the daLC would have failed their TH expression capacity. Since the volume and the mean limit of this subdivision remained constant between the two ages, it is likely that the "quiescent" cells were localized inside the space delineated by the cell bodies that continued to express TH gene. Indeed, the number of Nissl-stained neurons at PND21 was 38\% higher than the number of TH-immunoreactive neurons in the aLC.

In the posterior LC (at level 9 for instance) the superimposition of the spaces delineated by the TH-positive cell bodies at PND14, PND21, and PND42 suggests the existence of two pools of transient TH-expressing cells. These two pools could be distinguished by differences in the date at which they would lose their TH protein trait and by differences in their topological localization. When level 9 of these three ages were superimposed, a ventrolateral space could be distinguished at PND14 a ventrolateral space at the vicinity of the spaces observed at PND21 and PND42. Since this space was not detected at PND21 and beyond, a first pool of transient TH-expressing cells in the pLC may be contained in this space. This first pool would have lost its TH expression capacity between PND14 and PND21. In the "common" area of the three ages at level 9, the density of TH-expressing perikarya was the same at PND14 and PND21. It was higher at these two ages than at PND42 because the number of TH-expressing cells was also higher at PND14 and PND21 than at PND42. A second pool of transient TH-expressing cells would be located in this "common" area and would have lost its TH expression capacity beyond PND21.

Considering that these pools would be differentially localized and would lose their TH expression capacity at different developmental stages, they might constitute organized subsets of neurons that could be involved in specific functions.

\section{Possible mechanisms for the transient expression of $T H$ in neurons}

The transient enhancement of catecholaminergic cell number has been reported in PND17 balb C mice LC as compared to the adult stage (Touret et al., 1982). However the transient enhancement of catecholaminergic neuron number is not only relevant to the LC during its postnatal ontogeny but also to 
other CNS structures. There is some evidence for a transient expression of the $\mathrm{TH}$ protein trait in the CNS, in structures known to exhibit no or few and dispcrsed TH-cxpressing cells at adult age, such as the cerebral cortex of the rat (Specht et al., 1981; Berger et al., 1985) and the mouse (Satoh et al., 1990), the anterior olfactory nucleus (Nagatsu et al., 1990) and the striatum (Komori et al., 1991) of the mouse, the inferior colliculus (Jaeger and Joh, 1983) and the limbic system (Verney et al., 1988) of the rat. Although naturally occurring cell death is reported during postnatal development (Oppenheim, 1991; Janec and Burke, 1993), a different fate could be proposed for the transient TH-expressing cells after they would have lost their TH phenotypic characteristic.

In the $\mathrm{LC}$, the regulation of $\mathrm{TH}$ expression would be different in cells expressing TH at steady-state conditions and in "quiescent" cells. Classical TH-expressing cells would have the intrinsic ability to acquire phenotypic characters of $\mathrm{TH}$ expression (Dreyfus et al., 1983; Robinson et al., 1993). In contrast, the appearance of the heretofore unexpressed $\mathrm{TH}$ protein trait in neurons indicates that the TH expression in these cells was not predetermined but could be epigenetically regulated (Black et al., 1984). Temporal changes of the environment of "quiescent" cells could explain the temporal expression of TH gene in these cells. Factors governing this epigenetic regulation of $\mathrm{TH}$ gene expression in the perikarya of "quiescent" neurons would operate, for instance, in the target areas of these neurons (Iacovitli et al., 1987; Robinson et al., 1993). In the somatic environment of these "quiescent" neurons, TH expression could also be transsynaptically regulated (Tashiro et al., 1989, 1990; Baker et al., 1993; Weiser et al., 1993). In their environment, cells in the CNS are not only able to detect the presence of neurotransmitter but also humoral factors that could control TH gene expression in their target cells (Brawer et al., 1986; Simerly et al., 1989). In our model, the factors controlling TH expression in "quiescent" cells are still unknown. Temporal involvements of each population of these cells could have discriminating functions. The establishment of TH increased levels in the LC at the adult stage after physiological perturbations (Richard et al., 1988; Schmitt et al., 1993) or pharmacological treatments (Debure et al., 1992; Schmitt et al., 1993) could involve some population of transient $\mathrm{TH}$-expressing cells that appeared during development. In one of these models, Debure et al. (1992) have demonstrated in the LC of adult rat the existence of a "quiescent" TH-expressing cell population, whose TH gene has been awakened by the RU24722 administration. Some of these cells (the so-called "sleeping" cells) were supposed to be localized outside the space of control rat LC because of the enhancement of the volume delineated by the TH-expressing cells in the treated rats. Such cells may have expressed TH protein trait in earlier developmental stages and could correspond to a pool of transient TH-expressing cells suggested in this study. We have localized one pool of transient TH-expressing cells at the vicinity of the space of the adult LC, which would have failed its TH expression capacity between PND14 and PND21.

We determined with precision the cellular phenotypic characteristics of $\mathrm{I} H \mathrm{H}$ expression in the LC during postnatal development. Despite the lack of knowledge about the characterization of the transient TH-expressing cells, we suggested the existence of three different pools of such cells. It was particularly interesting to precisely determine where such cells are localized to characterize further their neurochemical identity when $\mathrm{TH}$ protein is not expressed. Further studies are obviously needed to apprehend factors governing the plasticity of $\mathrm{TH}$ expression in such topologically defined populations of cells.

\section{References}

Abercrombie M (1946) Estimation of nuclear population from microtome sections. Anat Rec 94:239-247.

Baker H, Morel K, Stone DM, Maruniak JA (1993) Adult naris closure profoundly reduces tyrosine hydroxylase expression in mouse olfactory bulb. Brain Res 614:109-116.

Berger B, Verney C, Gaspar P, Febvret A (1985) Transient expression of tyrosine hydroxylase immunoreactivity in some neurons of the rat neocortex during postnatal development. Dev Brain Res 23:141-144.

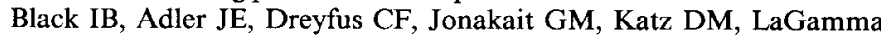
EF, Markey KM (1984) Neurotransmitter plasticity at the molecular level. Science 225:1266-1270.

Blanchard V, Raisman-Vorazi R, Savasta M, Hirsch E, Javoy-Agid F, Feuerstein C, Agid Y (1993) Cellular quantification of tyrosine hydroxylase in the rat brain by immunoautoradiography. J Neurochem 61:617-626.

Brawer J, Bertley J, Beaudet A (1986) Testosterone inhibition of tyrosine hydroxylase expression in the hypothalamic arcuate nucleus. Neurosci Lett 67:313-318.

Chamba G, Weissmann D, Rousset C, Renaud B, Pujol JF (1991) Distribution of alpha- 1 and alpha-2 binding sites in the rat locus coeruleus. Brain Res Bull 26:185-193.

Debure LI, Moyse E, Fevre-Montange M, Hardin H, Belin MF, Rousset C, Pujol JF, Wcissmann D (1992) Somatotopic organization of tyrosine hydroxylase expression in the rat locus coeruleus: long term effect of RU24722. Brain Res 581:19-32.

Dreyfus CF, Markey KA, Goldstein M, Black IB (1983) Development of catecholaminergic phenotypic characters in the mouse locus coeruleus in vivo and in culture. Dev Biol 97:48-58.

Ebosole P, Parnavelas JG, Blue ME (1981) Development of the visual cortex of rats treated with 6-hydroxydopamine in early life. Anat Embryol (Berl) 162:489-492.

Gagne C, Moyse E, Kocher L, Bour H, Pujol JF (1990) Light-microscopic localization of somatostatin binding sites in the locus coeruleus of the rat. Brain Res 530:196-204.

Iacovitti L, Lee J, Joh TH, Reis DJ (1987) Expression of tyrosine hydroxylase in neurons of cultured cerebral cortex: evidence for phenotypic plasticity in ncurons of the CNS. J Neurosci 7:1264-1270.

Jaeger CB, Joh TH (1983) Transient expression of tyrosine hydroxylase in some neurons of the developing inferior colliculus of the rat. Dev Brain Res 11:128-132.

Janec E, Burke RE (1993) Naturally occurring cell death during postnatal development of the substantia nigra pars compacta of rat. Mol Cell Neurosci 4:30-35.

Joh TH, Reis DJ (1975) Different forms of tyrosine hydroxylase in central dopaminergic and noradrenergic neurons and sympathetic ganglia. Brain Res 85:146-151.

Kasamatsu T, Pettigrew JD (1976) Depletion of brain catecholamines: failure of ocular dominance shift after monocular occlusion in kittens. Science 194:206-209.

Kasamatsu T, Pettigrew JD (1979) Preservation of binocularity after monocular deprivation in the striate cortex of kittens treated with 6-hydroxydopamine. J Comp Neurol 185:139-162.

Kasamatsu T, Ohashi T, Imamura K (1989) Integration of adrenergic and cholinergic regulation in ocular dominance plasticity. Biomed Res 10[Suppl 2]:43-53.

Komori K, Sakai M, Karasawa N, Yamada K, Nagatsu I (1991) Evidence for transient expression of tyrosine hydroxylase immunoreactivity in the mouse striatum and the effect of colchicine. Acta Histochem Cytochem 2:223-231.

Lauder JM, Bloom FE (1974) Ontogeny of monoamine neurons in the locus coeruleus, raphe nuclei and substantia nigra of the rat. I. Cell differentiation. J Comp Neurol 155:469_482.

Levitt M, Spector S, Sjoersma A, Udenfriend S (1965) Elucidation of the rate-limiting step in the norepinephrine biosynthesis in the perfused guinca-pig heart. J Pharmacol Exp Ther 148:1-8.

Lidov HGW, Molliver ME (1982) The structure of cerebral cortex in the rat following prenatal administration of 6-hydroxydopamine. Dev Brain Res 3:81-108.

Loughlin SE, Foote SL, Bloom FE (1986) Efferent projections of nucleus locus coeruleus: topographic organization of cells of origin dem- 
onstrated by three-dimensional reconstruction. Neuroscience 18:291306.

Luque JM, de Blas MR, Segovia S, Guillamon A (1992) Sexual dimorphism of the dopamine- $\beta$-hydroxylase-immunoreactive neurons in the rat locus ceruleus. Dev Brain Res 67:211-215.

Maeda T, Dresse A (1969) Recherches sur le développement du locus coeruleus. I. Etude des catecholamines au microscope de fluorescence. Acta Neurol Belg 69:5-10.

Maeda T, Tohyama M, Shimizu N (1974) Modification of postnatal development of neocortex in rat brain with experimental deprivation of locus coeruleus. Brain Res 70:515-520.

Nagatsu I, Komori K, Takeuchi T, Sakai M, Yamada K, Karasawa N (1990) Transient tyrosine hydroxylase-immunoreactive neurons in the region of the anterior olfactory nucleus of pre- and postnatal mice do not contain dopamine. Brain Res 511:55-62.

Nagatsu I, Levitt M, Udenfriend S (1964) Tyrosine hydroxylase. The initial step in norepinephrine synthesis. J Biol Chem 239:2910-2917.

Oppenheim RW (1991) Cell death during the development of the nervous system. Annu Rev Neurosci 14:453-501.

Parnavelas JG, Blue ME (1982) The role of the noradrenergic system on the formation of synapses in the visual cortex of the rat. Dev Brain Res 3:140-144.

Pickel VM, Joh TH, Field PM, Becker CG, Reis DJ (1975) Cellular localization of tyrosine hydroxylase by immunohistochemistry. J Histochem Cytochem 23:1-12.

Richard F, Faucon-Biguet N, Labatut R, Rollet D, Mallet J, Buda M (1988) Modulation of tyrosine hydroxylase gene expression in rat brain and adrenal by exposure to cold. J Neurosci Res 260:32-37.

Robinson LJ, Black IB, Dreyfus CF (1993) Hippocampal regulation of the survival and morphological development of locus coeruleus neurons in dissociated cell culture. J Comp Neurol 333:567-577.

Satoh J, Suzuki K (1990) Tyrosine hydroxylase-immunoreactive neurons in the mouse cerebral cortex during the postnatal period. Dev Brain Res 53:1-5.

Schmitt P, Reny-Palasse V, Bourde O, Garcia C, Pujol JF (1993a) Further characterization of the long-term effect of RU24722 on tyrosine hydroxylase in the rat locus coeruleus. J Neurochem 61:14231429.

Schmitt P, Pequignot J, Garcia C, Pujol JF, Pequignot JM (1993b) Regional specificity of the long-term regulation of tyrosine hydroxylase in some catecholaminergic rat brainstem areas. I. Influence of long-term hypoxia. Brain Res 611:53-60.

Schmitt P, Pequignot J, Hanchin F, Pujol JF, Pequignot JM (1993c) Regional specificity of long-term regulation of tyrosine hydroxylase in some catecholaminergic rat brain areas. II. Effect of a chronic dihydralazine treatment. Brain Res 611:61-66.

Seiger A, Olson L (1973) Late prenatal ontogeny of central monoamine neurons in the rat: fluorescence histochemical observations. Z Anat Entwicklungsgesch 140:281-318.
Sievers J, Lolova I, Jenner S, Klemm HP, Sievers H (1981) Morphological and biochemical studies on the ontogenesis of the nucleus locus coeruleus. Bibl Anat 19:52-130.

Simerly RB (1989) Hormonal control of the development and regulation of tyrosine hydroxylase expression within a sexually dimorphic population of dopaminergic cells in the hypothalamus. Mol Brain Res 6:297-310.

Specht LA, Pickel VM, Joh TH, Reis DJ (1981) Light-microscopic immunocytochemical localization of tyrosine hydroxylase in prenatal rat brain. I. Early ontogeny. J Comp Neurol 199:233-253.

Sternberger LA, Hardy X Jr, Cuculis PH, Mayer HG (1970) The unlabeled antibody-enzyme method of immunochemistry. Preparation and properties of soluble antigen-antibody complex (horseradish peroxidase-antihorseradish peroxidase) and its use in identification of spirochetes. J Histochem 18:315-339.

Swanson LW (1976) The locus coeruleus: a cytoarchitectonic, Golgi and immunohistochemical study in the albino rat. Brain Res 110:3956.

Tashiro T, Sugimoto T, Hattori T, Uemura Y, Nagatsu I, Kikuchi H, Mizuno N (1989) Tyrosine hydroxylase-like immunoreactive neurons in the striatum of the rat. Neurosci Lett 97:6-10.

Tashiro Y, Kaneko T, Nagatsu I, Kikuchi H, Mizuno N (1990) Increase of tyrosine hydroxylase-like immunoreactive neurons in the nucleus accumbens and the olfactory bulb in the rat with the lesion in the ventral tegmental area of the midbrain. Brain Res 531:159166.

Touret M, Valatx JL, Jouvet M (1982) The locus coeruleus: a quantitative and genetic study in mice. Brain Res 250:353-357.

Verney C, Berger B, Adrien J, Vigny A, Gay M (1982) Development of the dopaminergic innervation of the rat cerebral cortex. A light microscopic immunocytochemical study using anti-tyrosine hydroxylase antibodies. Dev Brain Res 5:41-52.

Verney C, Gaspar P, Febvret A, Berger B (1988) Transient tyrosine hydroxylase-like immunoreactive neurons contain somatostatin and substance $P$ in the developing amygdala and bed nucleus of the stria terminalis of the rat. Dev Brain Res 42:45-58.

Weiser M, Baker H, Wessel TC, Joh TH (1993) Axotomy-induced differential gene induction in neurons of the locus ceruleus and substantia nigra. Mol Brain Res 17:319-327.

Wcissmann D, Labatut R, Rousset C, Pujol JF (1989) Direct transfer into nitrocellulose and quantitative radioautographic anatomical determination of brain tyrosine hydroxylase protein concentration. $\mathrm{J}$ Neurochem 53:793-799.

Wendlandt S, Crow TJ, Stirling RV (1977) The involvement of the noradrenergic system arising from the locus coeruleus in the postnatal development of the cortex in rat brain. Brain Res 125:1-9.

Zyzek E, Richard F, Bouilloux JP, Pujol JF (1990) Ontogeny of tyrosine hydroxylase concentration in locus coeruleus of newborn rats: long-term effects of RU24722. J Neurochem 55:849-853. 